\title{
Obesity, type 2 diabetes, and cancer: the insulin and IGF connection
}

\author{
Dara Hope Cohen and Derek LeRoith
}

Division of Endocrinology, Diabetes and Bone Diseases, The Samuel Bronfman Department of Medicine, Mount Sinai School of Medicine, New York, New York 10029, USA

(Correspondence should be addressed to D LeRoith; Email: derek.leroith@mssm.edu)

\begin{abstract}
Epidemiological studies suggest a positive association between obesity and type 2 diabetes mellitus (T2D) with the risk of cancer and cancer-related mortality. Insulin resistance, hyperinsulinemia, increased levels of IGF, elevated levels of steroid and peptide hormones, and inflammatory markers appear to play a role in the connection between these different diseases. Medications, such as metformin and exogenous insulin, used to treat T2D may affect the risk of cancer and cancer-related mortality. Newer therapies targeting the insulin and IGF1 systems are being developed for use in cancer therapy.
\end{abstract}

Endocrine-Related Cancer (2012) 19 F27-F45

\section{Introduction}

Obesity and type 2 diabetes mellitus (T2D) have been demonstrated to have a positive association with both the risk of cancer and cancer-related mortality. Given the dramatic increase in the rates of obesity and T2D, this connection is of great public health concern. The link between obesity, T2D, and cancer appears to be related to insulin resistance, hyperinsulinemia, increased levels of IGF, steroid and peptide hormones, and inflammatory markers. Medications used to treat T2D can influence some of these factors and may affect the risk of cancer and cancer-related mortality. In this review, we present epidemiological evidence of the relationship between obesity, T2D, and cancer. We also review the available literature regarding the effects of exogenous insulin on the risk of cancer and cancerrelated mortality in patients with T2D. Additionally, the proposed mechanisms that connect obesity, T2D, and cancer and the data on newer anticancer therapies that target metabolic pathways are discussed.

\section{Epidemiological}

\section{Link between obesity, diabetes, and cancer}

In the past several decades, there has been a dramatic increase in the rates of obesity (defined as a body mass index (BMI) $\geq 30 \mathrm{~kg} / \mathrm{m}^{2}$ ). Currently, one-third of all adults in the United States are obese and similar trends have been observed worldwide. The World Health Organization (WHO) estimates that worldwide obesity has more than doubled since 1980. In 2008, 1.5 billion adults, aged 20 years and older, were overweight. Of these, over 200 million men and nearly 300 million women were obese (World Health Organization $2011 a, b)$. Obesity has many associated comorbidities, including T2D and cancer. The association between obesity and cancer has been recognized and widely studied. The results of the Cancer Prevention Study suggested that $14 \%$ of cancer deaths in men and $20 \%$ in women could be attributed to obesity (Calle et al. 2003). More recent evidence suggests that about onethird of the 571950 cancer deaths that were expected to occur in 2011 in the United States would be related to overweight or obesity, physical inactivity, and poor nutrition (American Cancer Society, Cancer Facts and Figures 2011 www.cancer.org/acs/groups/content/@ epidemiologysurveilance/documents/document/acspc029771.pdf). Meta-analyses of prospective studies from other parts of the world show similar findings (Bergstrom et al. 2001, Pan et al. 2004, Kuriyama et al. 2005).

With the worsening obesity epidemic, there has also been an increase in the rate of T2D. The CDC estimates that in the United States alone, there are 25.8 million people with diabetes, a number that comprises $8.3 \%$ of the population (Centers for Disease Control and Prevention, National diabetes fact sheet: national 
estimates and general information on diabetes and pre-diabetes in the United States www.cdc.gov/ diabetes/pubs/pdf/ndfs_2011.pdf). Diabetes is estimated to affect 346 million people worldwide (World Health Organization 2011a,b) and is expected to continue to increase to 366 million by 2030 , which is more than double the prevalence observed in the year 2000 (Wild et al. 2004). While a positive association between obesity and cancer has been observed, higher rates of cancer-related mortality have been seen in patients with $\mathrm{T} 2 \mathrm{D}$, regardless of BMI, suggesting that T2D may be an independent risk factor for cancer and cancer-related mortality (Calle \& Kaaks 2004, Xue \& Michels 2007). A recent meta-analysis of cohort and case-control studies examining the risk for specific cancers in patients with diabetes mellitus showed increases in the relative risk of liver, pancreatic, colorectal, bladder, endometrial, and breast cancers, and non-Hodgkin's lymphoma (Gallagher et al. $2010 b$ ). Insulin resistance, characterized by diminished responsiveness of the skeletal muscle, liver, and adipose tissue to insulin, and the subsequent hyperinsulinemia, or the compensatory rise in insulin levels in an attempt to maintain euglycemia, are key features of T2D (Kaaks \& Lukanova 2001). Hyperinsulinemia, which often predates the diagnosis of T2D for many years and persists early in the disease process, has been shown to link obesity and T2D to cancer. Other endocrine and metabolic effects of obesity such as increased levels of bioavailable IGF1, through effects on IGF-binding proteins (IGFBPs), play a role. Additionally, bioavailability of steroid and peptide hormones and systemic inflammation may contribute to the greater cancer risk in obesity and T2D.

\section{Mechanisms mediating increased cancer risk in obesity and T2D}

\section{Insulin and IGF1 receptors}

Insulin is produced by pancreatic $\beta$ cells, whereas IGF1 is produced in the liver. IGF1 is produced under the stimulus of $\mathrm{GH}$ acting on the $\mathrm{GH}$ receptor (GHR). Insulin and IGF1 mediate their intracellular effects via the activation of their cognate receptors, the insulin receptor (IR) and the IGF1 receptor (IGF1R) respectively. Both IGF1R and IR are heterotetrameric proteins (composed of one $\alpha-\beta$ dimer linked to a second $\alpha-\beta$ dimer by disulfide bonds) that possess intrinsic tyrosine kinase activity. IGF1R is expressed in nearly all the tissues of the body and activates mitogenic pathways resulting in cell proliferation (Frasca et al. 2008). Accordingly, increased IGFIR expression has been reported in several cancers (Gallagher \& LeRoith 2011).

The IR, on the other hand, undergoes alternative splicing of exon 11 resulting in two isoforms, IR-A and IR-B, that show spatiotemporal differences in their expression and also exert diverse functions (Mosthaf et al. 1990, Sciacca et al. 1999). IR-A is overly expressed in fetal and tumor cells and has more antiapoptotic and mitogenic effects (Frasca et al. 1999). On the other hand, IR-B is expressed by differentiated tissues such as the liver, adipocytes, and muscle, where it exerts the metabolic effect of insulin (Belfiore et al. 2009). In vitro studies have shown increased expression of IR-A in cancer cells (Mathieu et al. 1997, Sciacca et al. 2002) and elevated IR-A levels have been associated with tumor progression (Vella et al. 2002). One possible explanation for the mitogenic effects of IR-A compared with IR-B could be its ability to bind to the fetal growth factor IGF2, which is an effective impetus of cell proliferation during gestation (Frasca et al. 1999, Sciacca et al. 1999). Furthermore, recent data show that upon binding to IR-A, IGF2 activates a unique signaling pathway that differs from that of insulin (Morcavallo et al. 2011).

There is a high degree of homology between IGF1R and IR, and thus, they can form hybrid receptors consisting of one $\alpha-\beta$ subunit of the IR and one $\alpha-\beta$ subunit of the IGF1R (Samani et al. 2007). IGF1 and IGF2 have high affinity for the hybrid receptors compared with insulin (Soos et al. 1993, Bailyes et al. 1997, Pandini et al. 1999), suggesting that cells that express increased quantities of hybrid receptors will have increased activation of mitogenic signaling pathways. In fact, increased levels of hybrid receptors have been observed in many cancer tissues (Belfiore et al. 1999, Pandini et al. 1999).

\section{Insulin and IGF signaling}

Ligand binding to the IR, IGF1R, and IR/IGF1R hybrid receptors results in autotransphosphorylation of the $\beta$-subunit tyrosine kinase domains. This is followed by phosphorylation of additional tyrosine residues and recruitment of adaptor proteins such as IR substrates $1-4$. Tyrosine phosphorylation of the adaptor proteins results in the recruitment and activation of downstream effectors, among which the most predominant are the phosphotidyl inositol 3-kinase (PI3K)/AKT and mitogen-activated protein kinase (MAPK) signaling pathways. The MAPK signaling pathway is primarily responsible for cell growth and proliferation. On the other hand, the PI3K/AKT signaling pathway has diverse effects ranging from the regulation of 
metabolic processes, activation of antiapoptotic pathways, and the stimulation of protein synthesis (Belfiore \& Malaguarnera 2011). In fact, activation of the PI3K/AKT pathway has been reported in many types of cancers (Gallagher et al. 2011). Phosphatase and tensin homolog deleted on chromosome 10 (PTEN), which is a physiological inhibitor of the PI3K/AKT pathway and thus serves as a tumor suppressor, is very frequently mutated in cancer (LeRoith \& Roberts 2003, Yakar et al. 2005, Levine et al. 2006). Another mechanism by which PTEN may serve as a tumor suppressor is by terminating IGF2 signaling. Studies on mice that overexpress IGF2 demonstrate the existence of a negative feedback loop wherein IGF2 activates PTEN, which in turn inhibits IGF2 signaling (Moorehead et al. 2003). Also, human breast cancer MCF-7 cells that have lost PTEN demonstrate increased IGF2 signaling through the IGF1R or IR-A (Perks et al. 2007).

One of the targets of the PI3K/AKT pathway is the activation of mammalian target of rapamycin (mTOR), which is involved in cell survival, growth, and metabolism, and is an actively pursued target for cancer therapy. In fact, activation of mTOR has been seen in breast cancer cells and has been linked to resistance to trastuzumab and tamoxifen, both chemotherapeutic agents (Yakar et al. 2005).

\section{Insulin resistance}

In obesity and T2D, insulin resistance leads to chronic hyperinsulinemia. Epidemiological studies as well as in vivo studies have demonstrated that insulin resistance can lead to enhanced tumor growth. In the Women's Health Initiative (WHI) Study, women with higher insulin levels had an increased risk of developing colorectal and endometrial cancers (Gunter et al. 2008a,b). Similar findings were observed in the Physicians' Health Study and the European Prospective Investigation into Cancer and Nutrition (EPIC), in which c-peptide levels were associated with a higher risk of developing colorectal and endometrial cancers and an elevated risk of mortality from prostate cancer (Ma et al. 2004, 2008, Jenab et al. 2007). In accordance with these observations, rats fed a high-fat diet (HFD) to induce insulin resistance developed more aberrant crypt foci, which are precancerous lesions, in the colon in response to the carcinogen azoxymethane than rats that were more insulin sensitive (Tran et al. 2003).

Hyperinsulinemia may affect cancer risk not only through the direct mitogenic effects of insulin but also indirectly via increased production of IGF1. GH activation of its receptor, the GHR, in the liver results in the activation of pathways that increase IGF1 production and secretion. In the presence of insulin, hepatic GHR expression is increased leading to increased production of IGF1. Therefore, chronic hyperinsulinemia is associated with elevated circulating IGF1 levels (LeRoith \& Roberts 2003, Renehan et al. 2004). Insulin also suppresses IGFBP1 and -2, which serve to limit the bioavailability of IGF1 in the peripheral tissues (Calle \& Kaaks 2004). Thus, a chronic elevation of insulin may lead to increased levels of bioavailable IGF1. Additionally, increased levels of insulin lead to increased formation of hybrid receptors and may lead to insulin binding to the IGF1R, thereby enhancing mitogenic potential (Vigneri et al. 2009).

\section{IGFs and cancer}

Higher levels of IGF1 have been correlated with an elevated risk of cancer, as evidenced by meta-analyses and prospective epidemiological studies (Chen et al. 2009, Rinaldi et al. 2010). For example, in the Rancho Bernardo Study, which included 18 years of follow-up, men who had a baseline IGF1 level above $100 \mathrm{ng} / \mathrm{ml}$ had a 1.82 risk of cancer mortality compared with men with lower levels. In men who had a baseline IGF1 level over $200 \mathrm{ng} / \mathrm{ml}$, the risk was increased by 2.61 (Major et al. 2010). Samani et al. (2007) summarized several studies evaluating the expression level of both IGF1 and IGF2 in different human cancers and found an overall positive correlation.

\section{Exogenous insulin and cancer}

As the duration and severity of T2D progress, patients and physicians often turn to exogenous insulin as a means to control patients' hyperglycemia. Studies have shown an increase in cancer-related mortality in patients with T2D treated with insulin (Bowker et al. 2006). Currie et al. (2009) reported that patients treated with insulin had an increased risk of colorectal and pancreatic cancers compared with patients treated with metformin. Insulin analogs, developed as an alternative to human insulin, are commonly used in the treatment of T2D. In order to create the insulin analogs, human insulin has been modified to more accurately mimic the endogenous secretion of insulin. Altering the structure of the insulin molecule can alter and enhance its mitogenic activity (Zib \& Raskin 2006). The potential for increased cancer risk in patients treated with insulin analogs became a cause of alarm after a German study showed a dose-dependent increase in cancer risk in patients treated with one such analog, insulin glargine, compared with human insulin (Hemkens et al. 2009). 
A positive association with breast cancer incidence was also observed in Swedish women using insulin glargine (Jonasson et al. 2009). However, the Scottish Diabetes Research Network Epidemiology Group reported that patients receiving insulin glargine had the same incidence rates of cancer as those not receiving insulin glargine, with the exception of the subgroup analysis of breast cancer. The authors concluded that this difference was due to selection bias as the patients who developed breast cancer were older and potentially more ill at baseline (Colhoun 2009). All the early studies linking insulin glargine and increased cancer risk had design flaws and thus were criticized and found inconclusive (Renehan 2011). Newer studies have sought to explore the relationship between insulin glargine use and cancer risk without these same design flaws and to conclusively define this relationship. Ruiter et al. studied a cohort of incident users of insulin in The Netherlands and found that of the 19337 incident users of insulin, only 878 developed cancer. Interestingly, a lower risk of malignancy was observed in users of insulin glargine compared with human insulin. However, an increased risk in breast cancer was seen in users of insulin glargine compared with human insulin, and this association demonstrated a dose-response effect in the as-treated analysis (Ruiter et al. 2012). Suissa et al. (2011) specifically examined the long-term effects of insulin glargine on the risk of breast cancer and noted that while insulin glargine use was not associated with an increased risk of breast cancer during the first 5 years of use, the risk increased after 5 years of use for women who had been on human insulin before starting insulin glargine $(\mathrm{HR}=2.7)$. As newer studies with improved methodology are being published, the association between insulin glargine and cancer risk is being explored. Further studies are necessary to better clarify this relationship.

\section{Glucose, leptin, adiponectin, and inflammatory cytokines}

While hyperinsulinemia is a predominant complication in obesity and T2D, several other factors (such as blood glucose levels) and the circulating profile of adipokines (such as leptin and adiponectin) and cytokines (such as $\mathrm{TNF} \alpha$ and interleukins (IL)) are also abnormal in obesity and T2D, and their contribution to cancer risk and progression cannot be discounted. It has long been known that cancer cells take up more glucose, a phenomenon described as the Warburg effect (Herling et al. 2011). In fact, the increased glucose uptake by cancer cells is the basis for FDG-PET scans, which are currently used to visualize tumors in vivo (Vander Heiden 2011). However, most of the patients with T2D are both hyperglycemic and hyperinsulinemic, and thus, it is difficult to separate the effects of glucose and insulin. Nevertheless, increased intake of sugar and refined carbohydrates has been positively correlated with the risk of cancer (Krone \& Ely 2005). One mechanism by which glucose could induce cancer progression is by the induction of oxidative stress, which has been associated with cancer (Brown \& Bicknell 2001). Turturro et al. (2007) demonstrated that inducing hyperglycemia in the human breast cancer cell line MDA-MB-231 leads to increased expression of the oxidative stress-responsive gene, thioredoxin-interacting protein, and subsequent increased levels of reactive oxygen species. Thus, hyperglycemia in obesity and T2D could accelerate tumor growth and progression.

Leptin is produced primarily by white adipose tissue but can also be produced by cells of the mammary epithelium, ovary, placenta, brown adipose tissue, skeletal muscle, bone marrow, pituitary, liver, and fundal glands of the stomach (Maffei et al. 1995). Leptin levels correlate positively with white adipose tissue mass; therefore, leptin levels are increased in obesity (Paz-Filho et al. 2011). On the one hand, leptin regulates energy homeostasis by mediating food intake and expenditure through its action on the hypothalamus; on the other hand, it also stimulates cell growth, migration, and invasion (Garofalo \& Surmacz 2006). Additionally, leptin can increase the production of cytokines by macrophages, which further stimulate cancer cells (Trayhurn \& Wood 2004). Leptin expression is induced by hypoxia via the hypoxiainduced factor 1 , and hypoxia frequently occurs in solid tumors (Ambrosini et al. 2002, Grosfeld et al. 2002). Furthermore, leptin can promote neoangiogenesis through the induction and activation of proangiogenic factors, such as vascular endothelial growth factor, fibroblast growth factor 2, and matrix metalloproteases 2 and 9 (Park et al. 2001). Leptin can enhance endothelial cell growth and suppress apoptosis through a BCL2-dependent mechanism (Bouloumie et al. 1998, Sierra-Honigmann et al. 1998, Cao et al. 2001, Artwohl et al. 2002). In hormone-dependent neoplasms, i.e. breast and endometrial cancers, leptin can stimulate cancer growth by activating aromatase, leading to increased estrogen synthesis (Boden et al. 1996). Studies on esophageal, breast, colorectal, and prostate cancers, cell lines demonstrate increased cell proliferation in the presence of leptin (Dieudonne et al. 2002, Onuma et al. 2003, Somasundar et al. 2004, Endo et al. 2011). In vivo studies also suggest a role for 
leptin in stimulating cancer development and growth. In fact, leptin-deficient $o b / o b$ and leptin-resistant $d b / d b$ mice do not develop transgene-induced mammary tumors (Cleary et al. 2003, 2004). More studies are necessary to further define the role of leptin in cancer promotion.

Adiponectin is produced exclusively by adipocytes and is involved in the regulation of energy homeostasis and glucose and lipid metabolism. Unlike leptin, adiponectin negatively correlates with body fat and BMI. Adiponectin production is inhibited by the inflammatory cytokines that are secreted by adipose tissue in obese individuals (Wozniak et al. 2009, Liu \& Liu 2010). Adiponectin inhibits inflammation, atherogenesis, angiogenesis, and insulin resistance (Brakenhielm et al. 2004, Ahima 2006). In vitro studies show adiponectin to be an inhibitor of cell growth and proliferation in prostate, breast, and esophageal cancers (Bub et al. 2006, Konturek et al. 2008, Cleary \& Grossmann 2009). Human studies appear to corroborate these findings. Serum adiponectin levels have been shown to inversely correlate with the risk, stage, and grade of colorectal cancer (Gialamas et al. 2011). In postmenopausal women, reduced serum adiponectin levels have been associated with increased breast cancer incidence (Mantzoros et al. 2004). Endometrial cancer has been linked to low adiponectin levels in premenopausal women (Cust et al. 2007). The molecular mechanism by which adiponectin suppresses cancer growth is by the activation of AMPK, which suppresses mTOR and thus hinders cell proliferation (Kelesidis et al. 2006, Reiling \& Sabatini 2006, Kim et al. 2009). AMPK may also suppress tumor growth by upregulation of the p53 axis, reduction of cyclin D1 levels, and suppression of the cyclindependent kinases leading to G1 cell cycle arrest (Cazzaniga et al. 2009). Adiponectin also stimulates the tumor suppressor LKB1, which, in addition to inhibiting the metastasis, is also a physiological activator of AMPK (Saxena \& Sharma 2010).

T2D and obesity are proinflammatory conditions and are associated with increased production of inflammatory cytokines such as IL6 and TNF- $\alpha$ by adipose tissue (Eltzschig \& Carmeliet 2011). Elevated levels of IL6 have been observed in patients with breast cancer, prostate cancer, B-cell lymphoma, and myeloma (Gallagher et al. 2010a). TNF- $\alpha$ stimulates the development and advancement of many tumors by activating nuclear factor- $\kappa \mathrm{B}$ (Szlosarek et al. 2006). Thus, while hyperinsulinemia could be one of the predominant factors driving cancer progression in obesity and $\mathrm{T} 2 \mathrm{D}$, the contributions of other factors mentioned earlier cannot be neglected.

\section{Role of sex hormones}

Increased adipose tissue, as seen in obesity, results in increased expression of the enzyme aromatase, which is responsible for converting androgens to estrogens (McTernan et al. 2000). Additionally, obesity and insulin resistance lead to decreased production of sex hormone-binding globulin (SHBG), resulting in increased bioavailability of estrogen. The increase in estrogen levels is thought to play a role in the development of endometrial cancer and postmenopausal breast cancer and epidemiological studies support this connection (Calle \& Kaaks 2004). The estrogen receptor and the IGF1R can work together to activate MAPK, thus stimulating tumor cell proliferation (Lee et al. 1999). A recent study by Tworoger et al. (2011) demonstrated that women with increased estrogen levels had an elevated risk of postmenopausal breast cancer, which further increased in women with increased IGF1 and c-peptide. This suggests that it is the interplay of the increased estrogen and insulin and IGF1 that is involved in the development of postmenopausal breast cancer.

Multiple factors play a role in the link between obesity, T2D, and cancer. These include but are not limited to the intricate workings of the insulin and IGF systems, hyperinsulinemia and insulin resistance, hyperglycemia, elevated leptin, low adiponectin, increased inflammatory cytokines, and sex hormones.

\section{T2D, obesity, and site-specific cancers}

T2D and obesity have been associated with many different cancers. The Cancer Prevention Study II and the Million Women Study demonstrated an increased risk of cancer and cancer-related mortality from cancers of the esophagus, pancreas, colon, and rectum; non-Hodgkin's lymphoma; and multiple myeloma in women with elevated BMI (Calle et al. 2003, Reeves et al. 2007; Table 1). Results of meta-analyses show a higher risk of cancers of the liver, pancreas, colon and rectum, kidney, bladder, endometrium, and breast and non-Hodgkin's lymphoma in individuals with diabetes compared with those without diabetes (Huxley et al. 2005, Larsson et al. 2005, Vigneri et al. 2009, Gallagher et al. 2010b; Table 2). In this section, we will focus on the association between T2D, obesity, and cancers of the breast and prostate.

\section{T2D, obesity, and breast cancer}

Affecting one in every eight women in the United States, breast cancer is the most commonly diagnosed cancer (besides skin cancer) and has the highest rates of death among women. The link between T2D, 
Table 1 Obesity and relative risk of cancer and cancer mortality

\begin{tabular}{|c|c|c|}
\hline Study & Cancer site & Relative risk \\
\hline \multicolumn{3}{|l|}{ The Million Women Study } \\
\hline Women $\left(\mathrm{BMl}>30 \mathrm{~kg} / \mathrm{m}^{2}\right)$ & $\begin{array}{l}\text { All cancers } \\
\text { combined }\end{array}$ & $\begin{array}{l}\text { Incidence } 1.12 \\
\quad(95 \% \mathrm{Cl} 1.09-1.14)\end{array}$ \\
\hline \multicolumn{3}{|c|}{ Cancer Prevention Study II } \\
\hline Men $\left(\mathrm{BMI}>40 \mathrm{~kg} / \mathrm{m}^{2}\right)$ & $\begin{array}{l}\text { All cancers } \\
\text { combined }\end{array}$ & $\begin{array}{l}\text { Mortality } 1.52 \\
\qquad(95 \% \mathrm{Cl} 1.13-2.05)\end{array}$ \\
\hline \multicolumn{3}{|c|}{ Cancer Prevention Study II } \\
\hline Women $\left(\mathrm{BMl}>40 \mathrm{~kg} / \mathrm{m}^{2}\right)$ & $\begin{array}{l}\text { All cancers } \\
\text { combined }\end{array}$ & $\begin{array}{l}\text { Mortality } 1.62 \\
\quad(95 \% \mathrm{Cl} 1.40-1.87)\end{array}$ \\
\hline
\end{tabular}

obesity, and breast cancer has been studied well. The connection is thought to be due to the aforementioned factors, namely the insulin/IGF pathway via insulin resistance and hyperinsulinemia, dysregulation of sex hormones, inflammatory cytokines, and adipokines.

In vitro studies have established that proliferation of breast tissue and breast cancer cell lines is stimulated by insulin and IGF1 (Pollak et al. 1988, Arteaga \& Osborne 1989, Ish-Shalom et al. 1997, Chappell et al. 2001). Blockade of the IGF1R-binding domain has been shown to inhibit the effect of IGF1Rinduced growth in human breast cancer cell lines (Arteaga et al. 1989).

Rodent models of obesity have been utilized to better understand the connection between breast cancer and obesity. Rats fed a HFD develop increased breast tumors in response to the carcinogen 7,12 dimethylbenz(a)anthracene (Carroll \& Braden 1984, Braden \& Carroll 1986, Rose et al. 1993, Hakkak et al. 2005). Furthermore, transplanted tumor xenografts demonstrate more rapid growth in rodents on HFD (Nunez et al. 2008). HFD-induced obesity in rodents leads to insulin resistance, which in turn enhances tumor development. However, as stated earlier, inflammatory cytokines and adipokines may also play a role. Khalid et al. studied mice overexpressing the oncogene Her2/ $\mathrm{Neu}$ (also known as Erbb2) in the mammary gland (under the murine mammary tumor virus promoter) on an HFD. These mice have higher body weights and increased body fat compared with regular chow-fed mice but demonstrate no evidence of insulin resistance. There is no difference in the time of first tumor presentation or tumor growth rates between the mice fed HFD and mice fed regular chow. However, the mice on the HFD present with a second tumor earlier and also have more tumors. Despite this, the tumors isolated from the HFD-fed mice do not show any differences in proliferative index relative to those isolated from the regular chow-fed mice. Thus, the authors concluded that in the absence of significant insulin resistance, HFD-induced obesity promotes tumor development and not tumor growth (Khalid et al. 2010). Thus, more studies are necessary to determine which components of obesity contribute to an increased risk of breast cancer and breast cancer mortality.

In vivo studies using rodent models have also been used to examine whether T2D is an independent risk factor for breast cancer. The lipodystrophic A-ZIP mice have reduced brown adipose tissue, absent white adipose tissue, elevated glucose, insulin, free fatty acids, and triglycerides and express increased levels of inflammatory cytokines. When A-ZIP/F-1 mice are crossed with the C3 (1)/T-Ag mammary tumor model, the result is increased tumor incidence and decreased tumor latency (Nunez et al. 2006). However, as with the previous studies, the A-ZIP mice also demonstrate hyperglycemia and increased cytokine levels, which could also affect tumor growth. Our laboratory has developed the nonobese, hyperinsulinemic MKR mouse model of T2D, and we have extensively studied the effect of hyperinsulinemia on breast cancer. In the MKR model, dominant-negative IGF1R is expressed specifically in skeletal muscle under the muscle creatine kinase promoter. The resultant is a mouse that is insulin resistant, glucose intolerant but not

Table 2 Meta-analysis on the relative risk of cancer at different sites in patients with type 2 diabetes

\begin{tabular}{|c|c|c|}
\hline Study & Cancer site & $\begin{array}{l}\text { Relative risk } \\
\text { (case-control; cohort) }\end{array}$ \\
\hline $\begin{array}{l}\text { Larsson et al. } \\
\quad(2007)\end{array}$ & Breast & $\begin{array}{c}1.80(95 \% \mathrm{Cl} 1.05-1.32) \\
1.20(95 \% \mathrm{Cl} 1.11-1.30)\end{array}$ \\
\hline $\begin{array}{l}\text { Gallagher et al. } \\
\qquad(2010 b)\end{array}$ & Breast & $1.20(95 \% \mathrm{Cl} 1.12-1.28)$ \\
\hline $\begin{array}{l}\text { Kasper \& Gio- } \\
\text { vannucci } \\
(2006)\end{array}$ & Prostate & $\begin{array}{l}0.89(95 \% \text { Cl } 0.72-1.11) \\
\quad 0.81(95 \% \text { Cl } 0.71-0.92)\end{array}$ \\
\hline $\begin{array}{l}\text { Gallagher et al. } \\
\qquad(2010 b)\end{array}$ & Prostate & $0.84(95 \% \mathrm{Cl} 0.76-0.93)$ \\
\hline $\begin{array}{l}\text { Gallagher et al. } \\
\qquad(2010 b)\end{array}$ & Liver & $2.51(95 \% \mathrm{Cl} 1.90-3.20)$ \\
\hline $\begin{array}{l}\text { Huxley et al. } \\
\qquad(2005)\end{array}$ & Pancreas & $\begin{array}{c}1.94(95 \% \text { Cl } 1.53-2.46) \\
1.73(95 \% \text { Cl } 1.59-1.88)\end{array}$ \\
\hline $\begin{array}{l}\text { Gallagher et al. } \\
\qquad(2010 b)\end{array}$ & Pancreas & $1.82(95 \% \mathrm{Cl} 1.66-1.89)$ \\
\hline $\begin{array}{l}\text { Larsson et al. } \\
\qquad(2005)\end{array}$ & Colorectal & $\begin{array}{c}1.36(95 \% \mathrm{Cl} 1.23-1.50) \\
1.29(95 \% \mathrm{Cl} 1.16-1.43)\end{array}$ \\
\hline $\begin{array}{l}\text { Gallagher et al. } \\
\qquad(2010 b)\end{array}$ & Colorectal & $1.30(95 \% \mathrm{Cl} 1.20-1.40)$ \\
\hline $\begin{array}{l}\text { Gallagher et al. } \\
\quad(2010 b)\end{array}$ & Bladder & $1.24(95 \% \mathrm{Cl} 1.08-1.42)$ \\
\hline $\begin{array}{l}\text { Gallagher et al. } \\
\qquad(2010 b)\end{array}$ & $\mathrm{NHL}$ & $1.19(95 \%$ Cl 1.04-1.35) \\
\hline $\begin{array}{l}\text { Gallagher et al. } \\
(2010 b)\end{array}$ & Endometrial & $2.10(95 \% \mathrm{Cl} 1.75-2.53)$ \\
\hline
\end{tabular}


obese. Furthermore, the female MKR mice display mild dysglycemia and dyslipidemia, but normal levels of circulating inflammatory cytokines making them a good model to study the effects of T2D on mammary tumorigenesis independent of obesity. Female MKR mice injected orthotopically with mouse mammary carcinoma cells have enhanced tumor growth compared with control mice. Furthermore, tumors from the MKR mice demonstrate increased activation of the IR and IGF1R, as well as the PI3K/AKT/mTOR pathway. In fact, correcting the hyperinsulinemia in the MKR mice with a $\beta_{3}$-adrenergic receptor agonist, treating with small-molecule IR/IGF1R tyrosine kinase inhibitors (TKIs), and pharmacologically inhibiting the PI3K/AKT/mTOR pathway result in reduction of tumor sizes in the MKR mice to the level of the control mice, further validating that hyperinsulinemia is the predominant factor mediating the accelerated tumor growth seen in the MKR mice (Fierz et al. 2010a,b, Novosyadlyy et al. 2010, Gallagher et al. 2011).

Epidemiological studies have also demonstrated an association between hyperinsulinemia and breast cancer (Michels et al. 2003, Jee et al. 2005, Rapp et al. 2006, Larsson et al. 2007). Gunter et al. (2009) reported on a case cohort study of postmenopausal women without diabetes and found that fasting insulin levels were positively correlated with breast cancer risk, irrespective of obesity. The Nurses' Health Study showed that postmenopausal women with T2D had an increased risk of breast cancer, with a hazard ratio of 1.17, which was independent of body adiposity (Michels et al. 2003). Larsson et al. (2007) performed a meta-analysis and found that women with T2D had a $20 \%$ increased risk of developing breast cancer compared with their nondiabetic counterparts.

While rodent models have focused on insulin resistance, hyperinsulinemia, and inflammatory cytokines and adipokines as the link between T2D, obesity, and breast cancer, it is important to also consider the role of sex steroids in the development of breast cancer. As discussed earlier, insulin can increase bioavailable estrogen by stimulating aromatase activity and inhibiting the production of SHBG. In postmenopausal women, SHBG levels have been negatively correlated with breast cancer risk (Toniolo et al. 1995, Key et al. 2002, Zeleniuch-Jacquotte et al. 2004, Kaaks et al. 2005).

Patients with T2D and obesity not only have an increased risk of developing breast cancer but also an increased risk of breast cancer mortality. In the Cancer Prevention Study II, increased BMI was strongly positively associated with increased mortality in individuals with breast cancer (Calle et al. 2003). Multiple studies have demonstrated that diabetic patients with breast cancer have lower survival rates than patients without diabetes (Yancik et al. 2001, Verlato et al. 2003). Patterson et al. (2010) reported a more than twofold risk of all-cause mortality in women with breast cancer and T2D compared with nondiabetic breast cancer patients. Erickson et al. (2011) analyzed archived baseline blood samples from the Women's Healthy Eating and Living Study for hemoglobin A1C, a measure of chronic glycemia, among women with early-stage breast cancer and found that the risk of allcause mortality increased with increasing hemoglobin A1C. Schrauder et al. compared breast cancer patients with and without diabetes and found a higher risk for distant metastasis in the patients with diabetes (HR 2.28; 95\% CI 1.31-1.97). Additionally, the patients with diabetes had an increased risk of mortality compared with their nondiabetic counterparts (HR 1.92; 95\% CI 1.49-2.48; Schrauder et al. 2011). A recent meta-analyses of eight studies exploring the relationship between breast cancer and diabetes found that patients with breast cancer and preexisting diabetes had a significantly higher all-cause mortality risk (Peairs et al. 2011).

In vitro, in vivo, and epidemiological studies have suggested a connection between T2D, obesity, and breast cancer. Women with T2D and obesity appear to have an increased risk of both breast cancer and breast cancer-related mortality. Suggested mechanisms include the insulin/IGF pathway via insulin resistance and hyperinsulinemia, dysregulation of sex hormones, inflammatory cytokines, and adipokines. However, further studies are necessary to better define the association of T2D, obesity, and breast cancer.

\section{T2D, obesity, and prostate cancer}

Prostate cancer is the most commonly diagnosed cancer (besides skin cancer) in the United States, affecting approximately one in every six men. Its relationship with T2D and obesity differs from other types of cancer as many reports suggest an inverse association (Vigneri et al. 2009). In fact, two metaanalyses, one including studies from 1971 to 2002 and the second extending this analysis to 2005 , reported a decreased risk of prostate cancer (9 and 16\% respectively) in men with diabetes (Bonovas et al. 2004, Kasper \& Giovannucci 2006).

The metabolic syndrome is defined by the presence of three out of five of the following factors: elevated waist circumference, elevated triglycerides, reduced high-density lipoprotein cholesterol, increased blood 
pressure, and elevated fasting glucose (Alberti et al. 2009). A recently published Italian case-control study on risk factors for prostate cancer suggested that there was an increased risk of prostate cancer in men with the metabolic syndrome. However, when individual components of the metabolic syndrome were considered, the odds ratio of having prostate cancer was not significantly increased in the presence of elevated waist circumference or elevated fasting glucose, suggesting that prostate cancer risk is not enhanced by diabetes or abdominal obesity (Pelucchi et al. 2011).

Animal studies have yielded conflicting results on the effects of obesity on prostate cancer risk. HFD does not affect prostate carcinogenesis in Noble male rats (Leung et al. 2002). However, inoculation of human prostate carcinoma LNCaP cells into athymic mice fed a high carbohydrate/HFD results in increased tumor growth (Venkateswaran et al. 2007). Additionally, transgenic Hi-Myc mice fed a low-fat diet demonstrate a decreased incidence of prostate cancer (Kobayashi et al. 2008).

Elevated testosterone levels have been associated with an increased risk of prostate cancer (Shaneyfelt et al. 2000, Kasper \& Giovannucci 2006). Men with T2D and obesity often have low testosterone levels and this may help to explain the decreased rates of prostate cancer in these men. In fact, studies have suggested that as many as $43 \%$ of men with T2D have reduced total testosterone levels and as many as $57 \%$ have decreased free testosterone levels (Grossmann et al. 2008). Thus, as prostate cancer is positively associated with testosterone levels and men with T2D and obesity have low testosterone levels, it is reasonable to conclude that men with T2D and obesity have a lower risk of prostate cancer than men without these conditions. And in fact, many studies do support this conclusion. Stocks et al. (2007) reported a prospective study and found that men with increased insulin resistance and worsening glycemic control had a decreased risk of prostate cancer. Baradaran et al. (2009) found that men with diabetes of longer duration had a lower risk of prostate cancer than men who had diabetes for a shorter period of time.

Patients with T2D and obesity have a lower risk of prostate cancer, but an increased risk of mortality and poor outcome once prostate cancer is diagnosed. Ma et al. (2008) demonstrated that higher c-peptide concentrations were predictive of prostate cancerrelated mortality. T2D has been shown as a significant independent risk factor for a diagnosis of high-grade prostate cancer (Kang et al. 2011, Mitin et al. 2011). BMI has also been shown to correlate with the risk of a high-grade prostate cancer (Calle et al. 2003, Amling et al. 2004, Freedland et al.2008, 2009, De Nunzio et al. 2011). Suggested explanations for this worse outcome and increased mortality include increased proliferation of tumor cells triggered by higher concentrations of insulin, IGF, and glucose (Barone et al. 2008).

Another explanation for the increased mortality and poorer outcomes in T2D and obesity could be underdiagnosis of prostate cancer. T2D has been associated with a lower level of prostrate-specific antigen (PSA) (Werny et al. 2006, Fukui et al. 2008). Similarly, PSA may be decreased in patients with obesity as a result of hemodilution (Wu et al. 2011). Often in clinical practice, prostate biopsy and subsequent cancer detection are initiated following an elevated PSA on screening tests. Thus, if patients with T2D and obesity have lower PSA levels, they are less likely to undergo biopsy and prostate cancer is less likely to be diagnosed at an earlier stage. However, when these patients present with prostate cancer, it is at a later stage when they are symptomatic or have more overt signs of disease. In order to answer this question, the authors of the Reduction by Dutasteride of Prostate Cancer Events (REDUCE) trial, a 4-year international, multicenter double-blinded, placebo-controlled trial examined the relationship between diabetes and prostate cancer in 6427 men. In the REDUCE trial, all men underwent a prostate biopsy regardless of serum PSA. Results demonstrated that patients with diabetes were as likely to develop prostate cancer, both low and high grade, as individuals without diabetes. The authors suggest that the lower rates of prostate cancer in patients with diabetes may be partially due to lower serum PSA levels leading to fewer biopsies and less detection of disease in these men (Wu et al. 2011).

Studies suggest that men with T2D and obesity have a decreased risk of prostate cancer, but if men with these diseases develop prostate cancer, they are more likely to have poor outcomes and to die from their prostate cancer. Suggested explanations for this include lower testosterone and PSA levels in men with T2D and obesity. Other factors may also play a role. Thus, further studies in both animals and humans are necessary to further elucidate the complicated relationship between $\mathrm{T} 2 \mathrm{D}$, obesity, and prostate cancer.

\section{Targeted therapeutics}

The involvement of the insulin and IGF1 signaling pathways in cancer development and progression has led to the development of new cancer therapies that target these systems (Fig. 1). In this section, we review some of these therapies. 


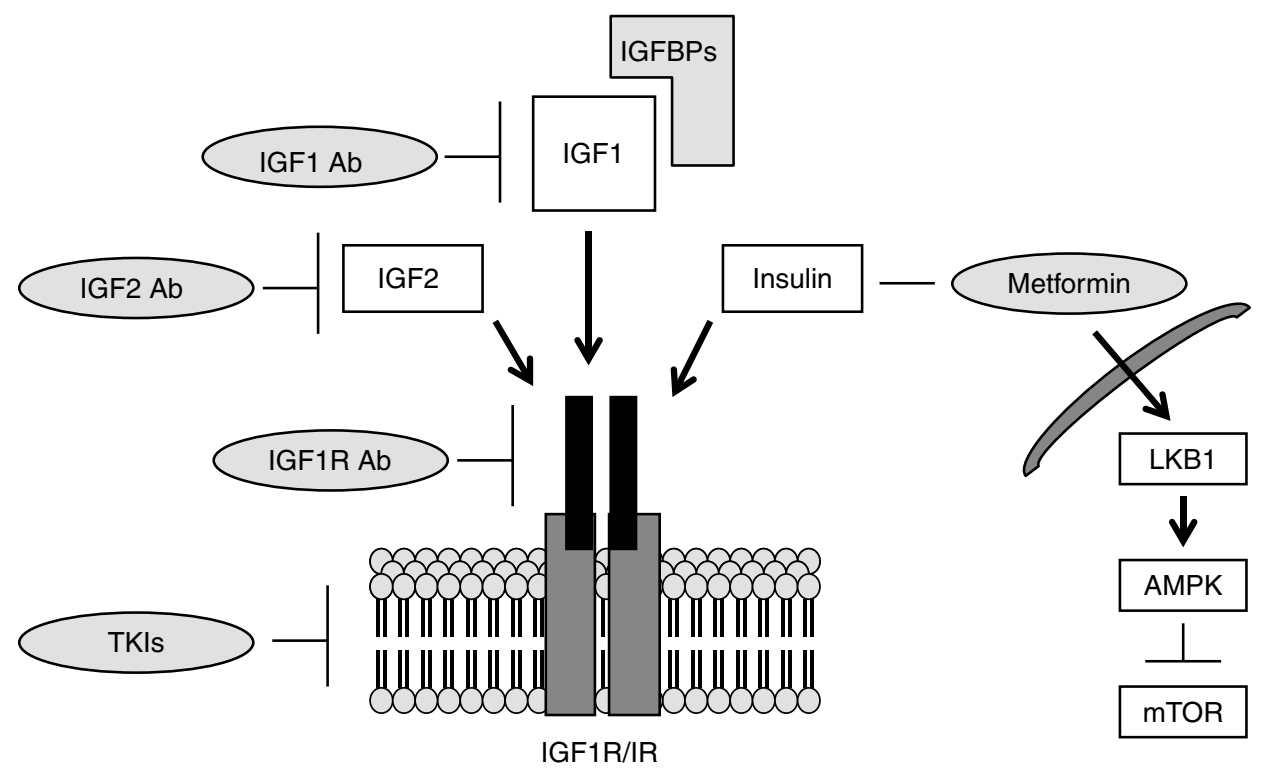

Figure 1 Schematic representation of anticancer therapies targeting insulin and IGF1 signaling. IGF1 and IGF2 bind to the IGF1R. Monoclonal antibodies directed at IGF1 and IGF2 have been developed and they prevent IGFs from interacting with the IGF1R. Monoclonal antibodies that block the IGF1R, thereby preventing the binding of insulin and IGF1 have also been developed. TKIs bind to the tyrosine kinase of the IGF1R and inhibit phosphorylation and subsequent activation of the receptor. Insulin can also bind to the IGF1R. As the IGF1R and IR are homologous, there is a cross-reactivity between the TKIs and the IR, which is why hyperglycemia is a common side effect of these medications. The IGF1 Ab and IGF2 Ab can cause hyperglycemia by inducing a compensatory increase in GH following IGF1 blockade and may also affect the IR by binding with hybrid receptors. Metformin is an insulin sensitizer and thus reduces insulin levels, providing less substrate for binding. Metformin also has a more direct inhibitory effect on cancer development and proliferation. Metformin activates LKB1, a tumor suppressor that activates AMPK, leading to mTOR inhibition, resulting in inhibited cell growth. Recombinant IGFBPs bind IGF1 and IGF2 without influencing the IR and are under development for use in cancer therapy. IGF1R, IGF1 receptor; IR, insulin receptor; IGF1 Ab, IGF1 antibodies; IGF1R Ab, IGF1R antibodies; IGFBPs, IGF-binding proteins; TKIs, tyrosine kinase inhibitors; LKB1, liver kinase B1; mTOR, mammalian target of rapamycin.

\section{Metformin and cancer}

Epidemiological studies have suggested a protective role for metformin in cancer development. Studies on patients with T2D on metformin have demonstrated a lower risk of cancer (Evans et al. 2005, Currie et al. 2009, Jiralerspong et al. 2009). In vitro studies corroborate these findings (Alimova et al. 2009, Kisfalvi et al. 2009, Cantrell et al. 2010, Rattan et al. 2011). Human breast cancer cells treated with metformin demonstrate inhibited proliferation and colony formation and increased cell cycle arrest (Alimova et al. 2009). It has been postulated that the effect of metformin on cancer development and progression may be a result of decreased levels of insulin and insulin resistance; however, studies have shown that metformin has a direct effect on tumor cell proliferation (Ben Sahra et al. 2010).

As stated previously, metformin activates AMPK. The AMPK/mTOR axis is modulated by liver kinase $\mathrm{B} 1$ (LKB1). LKB1 is a tumor suppressor that activates AMPK, leading to mTOR inhibition, resulting in inhibited cell growth (Ben Sahra et al. 2010). Zakikhani et al. (2006) demonstrated that metformin both upregulates AMPK activity and reduces general protein synthesis in MCF-7 human breast cancer cells, thereby functioning as a growth inhibitor. Additionally, Dowling et al. (2007) reported that metforminmediated AMPK activation results in mTOR inhibition and reduced translation initiation. On the other hand, several studies have suggested an AMPK-independent effect of metformin on cancer cells (Guigas et al. 2006, Ben Sahra et al. 2008). Therefore, it is possible that metformin has an AMPK-dependent effect on some cancer cell lines and an AMPK-independent effect on others (Ben Sahra et al. 2010).

In vivo studies suggest an antineoplastic effect of metformin. Female transgenic Her2/Neu mice treated with metformin demonstrate decreased incidence and size of mammary adenocarcinomas. Additionally, the mean latency of tumor development is increased with metformin treatment (Anisimov et al. 2005). Algire et al. (2008) studied the effect of metformin on highenergy diet-induced tumor progression. A higher tumor volume was observed in mice receiving the highenergy diet than control mice that was attenuated in the presence of metformin treatment. 
Human studies have shown similar results. Evans et al. demonstrated that treatment with metformin leads to a decreased risk of cancer in patients with T2D. A dose-response relationship was observed, as patients with the most exposure to metformin had the lowest rates of cancer (Evans et al. 2005). This doseresponse relationship was confirmed by a more recent study that demonstrated that long-term use of $\geq 40$ prescriptions ( $>5$ years) of metformin was associated with an odds ratio of 0.44 (95\% CI $0.24-0.82)$ for developing breast cancer compared with no use of metformin (Bodmer et al. 2010). Currie et al. (2009) reported that patients with $\mathrm{T} 2 \mathrm{D}$ treated with metformin had decreased rates of cancer compared with those on other antidiabetic treatments. In a nested case-control study from Denmark, women with T2D on metformin were less likely to develop breast cancer than women who were not taking metformin, OR 0.77 (95\% CI 0.61-0.99; Bosco et al. 2011).

Epidemiological studies have suggested that women who receive metformin for treatment of T2D not only have lower rates of breast cancer but also have better treatment response rates and lower rates of mortality from breast cancer (Jiralerspong et al. 2009, Landman et al. 2010). Jiralerspong et al. (2009) found that patients with early-stage breast cancer and T2D patients receiving metformin, in addition to neoadjuvant chemotherapy, had an increased rate of complete pathological response compared with patients with early-stage breast cancer and T2D not receiving metformin. In the Zwolle Outpatient Diabetes project Integrating Available Care (ZODIAC) study in The Netherlands, patients with T2D taking metformin had a lower hazard ratio for cancer mortality, 0.43 (95\% CI $0.23-0.80$ ), and the hazard ratio with every $1 \mathrm{~g}$ increase in metformin was 0.58 (95\% CI 0.36-0.93; Landman et al. 2010). Several clinical trials are now being conducted to determine whether metformin has clinically significant anticancer effects in patients without T2D. Additionally, the positive results seen with metformin have led to the development of other AMPK inhibitors that are currently under investigation (Park et al. 2009, Zhou et al. 2009).

\section{IGF1- and IGF1R-targeted receptors}

Monoclonal antibodies targeting the IGF1 peptide and the IGF1R have been studied for use in cancer treatment. Administration of antibodies to IGF1 (KM3168) and IGF2 (KM1468) to transgenic mice with a predisposition toward development of colon polyps results in reduced polyp formation. When combined, these two antibodies demonstrate an additive effect (Matsunaka et al. 2010). Treatment with these antibodies also leads to inhibition of bone metastases in prostate cancer cells (Goya et al. 2004). Similar agents are in phase I clinical trials.

Monoclonal antibodies directed at the IGF1R target the IGF1 system by binding to the $\alpha$ receptor of the IGF1R, thereby preventing the binding of IGF1 and IGF2. They also increase the internalization of the IGF1R, hence decreasing the number of receptors available for binding IGF1 and IGF2. The overall result is inhibition of the IGF1R signaling cascade (Heidegger et al. 2011). In vitro and in vivo studies with the monoclonal antibody robatumumab lead to inhibition of neuroblastoma, osteosarcoma, and rhabdomyosarcoma tumor cells and xenografts (Wang et al. 2010). Studies using the IGF1R antibody AVE1642 demonstrate an inhibition of metastasis in metastatic breast cancer cell lines (Sachdev et al. 2010). Several of these agents are undergoing preclinical testing and are in clinical trials for the treatment of both hematological and sold malignancies (Haluska et al. 2007, Lacy et al. 2008, Heidegger et al. 2011). As early clinical studies have appeared promising, several phase II and III trials were initiated to evaluate these agents. The most common side effect observed is hyperglycemia, which is likely caused by a compensatory increase in GH following IGF1 blockade, however, and may also affect the IR by binding with hybrid receptors (del Rincon et al. 2007). Studies have been disappointing as limited efficacy and a high degree of side effects have led to cessation of several of these trials and concern over the continued use of these agents (Heidegger et al. 2011). Thus, more studies are necessary in order to optimize the therapeutic benefit of these medications, while minimizing their toxicities in cancer therapy.

\section{Tyrosine kinase inhibitors}

As the IR and the IGF1R are tyrosine kinase receptors that require tyrosine kinase activity for effective signal transduction and these receptors have been demonstrated to play a role in cancer development and progression, TKIs have been evaluated for use in cancer therapy. TKIs compete for the ATP-binding site on the tyrosine kinase, blocking insulin and IGF1 signaling (Clemmons 2007). In vitro studies using the TKI BMS-554417 demonstrate inhibition of the IGF1R and IR kinase activity and proliferation of various cancer cell lines. Treatment with this agent also leads to reduced tumor xenograft size in vivo (Haluska et al. 2006). The TKI BMS-754807 inhibits the growth of osteosarcoma, rhabdomyosarcoma, neuroblastoma, liposarcoma, breast, lung, pancreatic, colon, gastric 
tumors, and multiple myeloma and leukemia cell lines. In addition, treatment with this agent in xenograft tumor models leads to tumor growth inhibition (Carboni et al. 2009). Treatment of female MKR mice with the TKI BMS-536924 also results in diminished tumor growth (Novosyadlyy et al. 2010). The TKI OSI-906 has been shown to have antitumor activity in adrenocortical carcinoma and is currently undergoing a phase III trial (NCT00924989). Phase I and II trials using TKIs in cancers of the lung and breast and other solid tumors are ongoing (Heidegger et al. 2011). The most common side effect observed with use of the TKIs is hyperglycemia as the binding site is conserved between the IR add IGF1R and insulin signaling can be inhibited (Heidegger et al. 2011). Thus, further study of these agents is necessary.

\section{Conclusion}

Epidemiological studies suggest that obesity and T2D are positively correlated with both the risk of cancer and cancer-related mortality. The link between obesity, $\mathrm{T} 2 \mathrm{D}$, and cancer is related to insulin resistance, hyperinsulinemia, and increased levels of IGF1, as well as augmented levels of steroid and peptide hormones and inflammatory markers. Medications used to treat T2D may affect the risk of cancer and cancer-related mortality. Hyperinsulinemia and augmented insulin and IGF1 signaling can enhance tumor development and growth. Newer therapies targeting these systems are being studied and show great promise as cancer treatments; however, further studies are necessary to better define their optimal utility.

\section{Declaration of interest}

The authors declare that there is no conflict of interest that could be perceived as prejudicing the impartiality of the research reported.

\section{Funding}

This research did not receive any specific grant from any funding agency in the public, commercial or not-for-profit sector.

\section{Acknowledgements}

The authors would like to thank Archana Vijayakumar for her careful review of the manuscript.

\section{References}

Ahima RS 2006 Adipose tissue as an endocrine organ. Obesity 14 (Suppl 5) 242S-249S. (doi:10.1038/oby.2006.317)
Alberti KG, Eckel RH, Grundy SM, Zimmet PZ, Cleeman JI, Donato KA, Fruchart JC, James WP, Loria CM \& Smith SC Jr 2009 Harmonizing the metabolic syndrome: a joint interim statement of the International Diabetes Federation Task Force on Epidemiology and Prevention; National Heart, Lung, and Blood Institute; American Heart Association; World Heart Federation; International Atherosclerosis Society; and International Association for the Study of Obesity. Circulation 120 1640-1645. (doi:10.1161/CIRCULATIONAHA.109.192644)

Algire C, Zakikhani M, Blouin MJ, Shuai JH \& Pollak M 2008 Metformin attenuates the stimulatory effect of a high-energy diet on in vivo LLC1 carcinoma growth. Endocrine-Related Cancer 15 833-839. (doi:10.1677/ ERC-08-0038)

Alimova IN, Liu B, Fan Z, Edgerton SM, Dillon T, Lind SE \& Thor AD 2009 Metformin inhibits breast cancer cell growth, colony formation and induces cell cycle arrest in vitro. Cell Cycle 8 909-915. (doi:10.4161/cc.8.6.7933)

Ambrosini G, Nath AK, Sierra-Honigmann MR \&

Flores-Riveros J 2002 Transcriptional activation of the human leptin gene in response to hypoxia. Involvement of hypoxia-inducible factor 1. Journal of Biological Chemistry 277 34601-34609. (doi:10.1074/jbc. M205172200)

Amling CL, Riffenburgh RH, Sun L, Moul JW, Lance RS, Kusuda L, Sexton WJ, Soderdahl DW, Donahue TF, Foley JP et al. 2004 Pathologic variables and recurrence rates as related to obesity and race in men with prostate cancer undergoing radical prostatectomy. Journal of Clinical Oncology 22 439-445. (doi:10.1200/JCO.2004. 03.132)

Anisimov VN, Berstein LM, Egormin PA, Piskunova TS, Popovich IG, Zabezhinski MA, Kovalenko IG, Poroshina TE, Semenchenko AV, Provinciali M et al. 2005 Effect of metformin on life span and on the development of spontaneous mammary tumors in HER-2/neu transgenic mice. Experimental Gerontology 40 685-693. (doi:10.1016/j.exger.2005.07.007)

Arteaga CL \& Osborne CK 1989 Growth inhibition of human breast cancer cells in vitro with an antibody against the type I somatomedin receptor. Cancer Research 49 6237-6241.

Arteaga CL, Kitten LJ, Coronado EB, Jacobs S, Kull FC Jr, Allred DC \& Osborne CK 1989 Blockade of the type I somatomedin receptor inhibits growth of human breast cancer cells in athymic mice. Journal of Clinical Investigation 84 1418-1423. (doi:10.1172/JCI114315)

Artwohl M, Roden M, Holzenbein T, Freudenthaler A, Waldhausl W \& Baumgartner-Parzer SM 2002 Modulation by leptin of proliferation and apoptosis in vascular endothelial cells. International Journal of Obesity and Related Metabolic Disorders 26 577-580. (doi:10.1038/ sj.ijo.0801947)

Bailyes EM, Nave BT, Soos MA, Orr SR, Hayward AC \& Siddle K 1997 Insulin receptor/IGF-I receptor hybrids are widely distributed in mammalian tissues: quantification of 
individual receptor species by selective immunoprecipitation and immunoblotting. Biochemical Journal 327 209-215.

Baradaran N, Ahmadi H, Salem S, Lotfi M, Jahani Y, Mehrsai AR \& Pourmand G 2009 The protective effect of diabetes mellitus against prostate cancer: role of sex hormones. Prostate 69 1744-1750. (doi:10.1002/pros. 21023)

Barone BB, Yeh HC, Snyder CF, Peairs KS, Stein KB, Derr RL, Wolff AC \& Brancati FL 2008 Long-term all-cause mortality in cancer patients with preexisting diabetes mellitus: a systematic review and metaanalysis. Journal of the American Medical Association 300 2754-2764. (doi:10.1001/jama.2008.824)

Belfiore A \& Malaguarnera R 2011 Insulin receptor and cancer. Endocrine-Related Cancer 18 R125-R147. (doi:10.1530/ERC-11-0074)

Belfiore A, Pandini G, Vella V, Squatrito S \& Vigneri R 1999 Insulin/IGF-I hybrid receptors play a major role in IGF-I signaling in thyroid cancer. Biochimie 81 403-407. (doi:10.1016/S0300-9084(99)80088-1)

Belfiore A, Frasca F, Pandini G, Sciacca L \& Vigneri R 2009 Insulin receptor isoforms and insulin receptor/insulin-like growth factor receptor hybrids in physiology and disease. Endocrine Reviews 30 586-623. (doi:10.1210/er.20080047)

Ben Sahra I, Laurent K, Loubat A, Giorgetti-Peraldi S, Colosetti P, Auberger P, Tanti JF, Le Marchand-Brustel Y \& Bost F 2008 The antidiabetic drug metformin exerts an antitumoral effect in vitro and in vivo through a decrease of cyclin D1 level. Oncogene 27 3576-3586. (doi:10.1038/sj.onc.1211024)

Ben Sahra I, Le Marchand-Brustel Y, Tanti JF \& Bost F 2010 Metformin in cancer therapy: a new perspective for an old antidiabetic drug? Molecular Cancer Therapeutics 9 1092-1099. (doi:10.1158/1535-7163.MCT-09-1186)

Bergstrom A, Pisani P, Tenet V, Wolk A \& Adami HO 2001 Overweight as an avoidable cause of cancer in Europe. International Journal of Cancer 91 421-430. (doi:10. 1002/1097-0215(200002)9999:9999 <::AID-IJC1053> 3.0.CO;2-T)

Boden G, Chen X, Mozzoli M \& Ryan I 1996 Effect of fasting on serum leptin in normal human subjects. Journal of Clinical Endocrinology and Metabolism 81 3419-3423. (doi:10.1210/jc.81.9.3419)

Bodmer M, Meier C, Krahenbuhl S, Jick SS \& Meier CR 2010 Long-term metformin use is associated with decreased risk of breast cancer. Diabetes Care $\mathbf{3 3}$ 1304-1308. (doi:10.2337/dc09-1791)

Bonovas S, Filioussi K \& Tsantes A 2004 Diabetes mellitus and risk of prostate cancer: a meta-analysis. Diabetologia 47 1071-1078. (doi:10.1007/s00125-004-1415-6)

Bosco JL, Antonsen S, Sorensen HT, Pedersen L \& Lash TL 2011 Metformin and incident breast cancer among diabetic women: a population-based case-control study in Denmark. Cancer Epidemiology, Biomarkers \& Prevention 20 101-111. (doi:10.1158/1055-9965.EPI-10-0817)
Bouloumie A, Drexler HC, Lafontan M \& Busse R 1998 Leptin, the product of $\mathrm{Ob}$ gene, promotes angiogenesis. Circulation Research 83 1059-1066.

Bowker SL, Majumdar SR, Veugelers P \& Johnson JA 2006 Increased cancer-related mortality for patients with type 2 diabetes who use sulfonylureas or insulin. Diabetes Care 29 254-258. (doi:10.2337/diacare.29.02.06.dc05-1558)

Braden LM \& Carroll KK 1986 Dietary polyunsaturated fat in relation to mammary carcinogenesis in rats. Lipids $\mathbf{2 1}$ 285-288. (doi:10.1007/BF02536414)

Brakenhielm E, Veitonmaki N, Cao R, Kihara S, Matsuzawa Y, Zhivotovsky B, Funahashi T \& Cao Y 2004 Adiponectin-induced antiangiogenesis and antitumor activity involve caspase-mediated endothelial cell apoptosis. PNAS 101 2476-2481. (doi:10.1073/pnas. 0308671100)

Brown NS \& Bicknell R 2001 Hypoxia and oxidative stress in breast cancer. Oxidative stress: its effects on the growth, metastatic potential and response to therapy of breast cancer. Breast Cancer Research 3 323-327. (doi:10.1186/bcr315)

Bub JD, Miyazaki T \& Iwamoto Y 2006 Adiponectin as a growth inhibitor in prostate cancer cells. Biochemical and Biophysical Research Communications 340 1158-1166. (doi:10.1016/j.bbrc.2005.12.103)

Calle EE \& Kaaks R 2004 Overweight, obesity and cancer: epidemiological evidence and proposed mechanisms. Nature Reviews. Cancer 4 579-591. (doi:10.1038/ nrc1408)

Calle EE, Rodriguez C, Walker-Thurmond K \& Thun MJ 2003 Overweight, obesity, and mortality from cancer in a prospectively studied cohort of U.S. adults. New England Journal of Medicine 348 1625-1638. (doi:10.1056/ NEJMoa021423)

Cantrell LA, Zhou C, Mendivil A, Malloy KM, Gehrig PA \& Bae-Jump VL 2010 Metformin is a potent inhibitor of endometrial cancer cell proliferation - implications for a novel treatment strategy. Gynecologic Oncology 116 92-98. (doi:10.1016/j.ygyno.2009.09.024)

Cao R, Brakenhielm E, Wahlestedt C, Thyberg J \& Cao Y 2001 Leptin induces vascular permeability and synergistically stimulates angiogenesis with FGF-2 and VEGF. PNAS 98 6390-6395. (doi:10.1073/pnas.101564798)

Carboni JM, Wittman M, Yang Z, Lee F, Greer A, Hurlburt W, Hillerman S, Cao C, Cantor GH, Dell-John J et al. 2009 BMS-754807, a small molecule inhibitor of insulin-like growth factor-1R/IR. Molecular Cancer Therapeutics 8 3341-3349. (doi:10.1158/1535-7163. MCT-09-0499)

Carroll KK \& Braden LM 1984 Dietary fat and mammary carcinogenesis. Nutrition and Cancer 6 254-259. (doi:10.1080/01635588509513831)

Cazzaniga M, Bonanni B, Guerrieri-Gonzaga A \& Decensi A 2009 Is it time to test metformin in breast cancer clinical trials? Cancer Epidemiology, Biomarkers \& Prevention 18 701-705. (doi:10.1158/1055-9965.EPI-08-0871) 
Chappell J, Leitner JW, Solomon S, Golovchenko I, Goalstone ML \& Draznin B 2001 Effect of insulin on cell cycle progression in MCF-7 breast cancer cells. Direct and potentiating influence. Journal of Biological Chemistry 276 38023-38028. (doi:10.1074/jbc.M10 6008200)

Chen W, Wang S, Tian T, Bai J, Hu Z, Xu Y, Dong J, Chen F, Wang X \& Shen H 2009 Phenotypes and genotypes of insulin-like growth factor 1, IGF-binding protein-3 and cancer risk: evidence from 96 studies. European Journal of Human Genetics 17 1668-1675. (doi:10.1038/ ejhg.2009.86)

Cleary MP \& Grossmann ME 2009 Minireview: obesity and breast cancer: the estrogen connection. Endocrinology 150 2537-2542. (doi:10.1210/en.2009-0070)

Cleary MP, Phillips FC, Getzin SC, Jacobson TL, Jacobson MK, Christensen TA, Juneja SC, Grande JP \& Maihle NJ 2003 Genetically obese MMTV-TGF-alpha/ Lep(ob)Lep(ob) female mice do not develop mammary tumors. Breast Cancer Research and Treatment 77 205-215. (doi:10.1023/A:1021891825399)

Cleary MP, Grande JP, Juneja SC \& Maihle NJ 2004 Dietinduced obesity and mammary tumor development in MMTV-neu female mice. Nutrition and Cancer 50 174-180. (doi:10.1207/s15327914nc5002_7)

Clemmons DR 2007 Modifying IGF1 activity: an approach to treat endocrine disorders, atherosclerosis and cancer. Nature Reviews. Drug Discovery 6 821-833. (doi:10.1038/nrd2359)

Colhoun HM 2009 Use of insulin glargine and cancer incidence in Scotland: a study from the Scottish Diabetes Research Network Epidemiology Group. Diabetologia 52 1755-1765. (doi:10.1007/s00125-009-1453-1)

Currie CJ, Poole CD \& Gale EA 2009 The influence of glucose-lowering therapies on cancer risk in type 2 diabetes. Diabetologia 52 1766-1777. (doi:10.1007/ s00125-009-1440-6)

Cust AE, Kaaks R, Friedenreich C, Bonnet F, Laville M, Lukanova A, Rinaldi S, Dossus L, Slimani N, Lundin E et al. 2007 Plasma adiponectin levels and endometrial cancer risk in pre- and postmenopausal women. Journal of Clinical Endocrinology and Metabolism 92 255-263. (doi:10.1210/jc.2006-1371)

De Nunzio C, Freedland SJ, Miano L, Finazzi Agro E, Banez L \& Tubaro A 2011 The uncertain relationship between obesity and prostate cancer: an Italian biopsy cohort analysis. European Journal of Surgical Oncology 37 1025-1029. (doi:10.1016/j.ejso.2011.09.036)

Dieudonne MN, Machinal-Quelin F, Serazin-Leroy V, Leneveu MC, Pecquery R \& Giudicelli Y 2002 Leptin mediates a proliferative response in human MCF7 breast cancer cells. Biochemical and Biophysical Research Communications 293 622-628. (doi:10.1016/S0006291X(02)00205-X)

Dowling RJ, Zakikhani M, Fantus IG, Pollak M \& Sonenberg N 2007 Metformin inhibits mammalian target of rapamycin-dependent translation initiation in breast cancer cells. Cancer Research 67 10804-10812. (doi:10.1158/0008-5472.CAN-07-2310)

Eltzschig HK \& Carmeliet P 2011 Hypoxia and inflammation. New England Journal of Medicine 364 656-665. (doi:10.1056/NEJMra0910283)

Endo H, Hosono K, Uchiyama T, Sakai E, Sugiyama M, Takahashi H, Nakajima N, Wada K, Takeda K, Nakagama $\mathrm{H}$ et al. 2011 Leptin acts as a growth factor for colorectal tumours at stages subsequent to tumour initiation in murine colon carcinogenesis. Gut 60 1363-1371. (doi:10.1136/gut.2010.235754)

Erickson K, Patterson RE, Flatt SW, Natarajan L, Parker BA, Heath DD, Laughlin GA, Saquib N, Rock CL \& Pierce JP 2011 Clinically defined type 2 diabetes mellitus and prognosis in early-stage breast cancer. Journal of Clinical Oncology 29 54-60. (doi:10.1200/JCO.2010.29. 3183)

Evans JM, Donnelly LA, Emslie-Smith AM, Alessi DR \& Morris AD 2005 Metformin and reduced risk of cancer in diabetic patients. BMJ 330 1304-1305. (doi:10.1136/bmj. 38415.708634.F7)

Fierz Y, Novosyadlyy R, Vijayakumar A, Yakar S \& LeRoith D $2010 a$ Insulin-sensitizing therapy attenuates type 2 diabetes-mediated mammary tumor progression. Diabetes 59 686-693. (doi:10.2337/db09-1291)

Fierz Y, Novosyadlyy R, Vijayakumar A, Yakar S \& LeRoith D $2010 b$ Mammalian target of rapamycin inhibition abrogates insulin-mediated mammary tumor progression in type 2 diabetes. Endocrine-Related Cancer 17 941-951. (doi:10.1677/ERC-10-0091)

Frasca F, Pandini G, Scalia P, Sciacca L, Mineo R, Costantino A, Goldfine ID, Belfiore A \& Vigneri R 1999 Insulin receptor isoform $\mathrm{A}$, a newly recognized, highaffinity insulin-like growth factor II receptor in fetal and cancer cells. Molecular and Cellular Biology 19 3278-3288.

Frasca F, Pandini G, Sciacca L, Pezzino V, Squatrito S, Belfiore A \& Vigneri R 2008 The role of insulin receptors and IGF-I receptors in cancer and other diseases. Archives of Physiology and Biochemistry 114 23-37. (doi:10.1080/ 13813450801969715)

Freedland SJ, Wen J, Wuerstle M, Shah A, Lai D, Moalej B, Atala C \& Aronson WJ 2008 Obesity is a significant risk factor for prostate cancer at the time of biopsy. Urology 72 1102-1105. (doi:10.1016/j.urology.2008. 05.044)

Freedland SJ, Banez LL, Sun LL, Fitzsimons NJ \& Moul JW 2009 Obese men have higher-grade and larger tumors: an analysis of the duke prostate center database. Prostate Cancer and Prostatic Disease 12 259-263. (doi:10.1038/ pcan.2009.11)

Fukui M, Tanaka M, Kadono M, Imai S, Hasegawa G, Yoshikawa T \& Nakamura N 2008 Serum prostatespecific antigen levels in men with type 2 diabetes. Diabetes Care 31 930-931. (doi:10.2337/dc07-1962) 
Gallagher EJ \& LeRoith D 2011 Minireview: IGF, insulin, and cancer. Endocrinology 152 2546-2551. (doi:10.1210/ en.2011-0231)

Gallagher EJ, Novosyadlyy R, Yakar S \& LeRoith D $2010 a$ The Increased Risk of Cancer in Obesity and Type 2 Diabetes: Potential Mechanisms. US: Springer.

Gallagher EJ, Fierz Y, Ferguson RD \& LeRoith D $2010 b$ The pathway from diabetes and obesity to cancer, on the route to targeted therapy. Endocrine Practice 16 864-873. (doi:10.4158/EP10098.RA)

Gallagher EJ, Fierz Y, Vijayakumar A, Haddad N, Yakar S \& Leroith D 2011 Inhibiting PI3K reduces mammary tumor growth and induces hyperglycemia in a mouse model of insulin resistance and hyperinsulinemia. Oncogene 31 3213-3222. (doi:10.1038/onc.2011.495)

Garofalo C \& Surmacz E 2006 Leptin and cancer. Journal of Cellular Physiology 207 12-22. (doi:10.1002/jcp.20472)

Gialamas SP, Petridou ET, Tseleni-Balafouta S, Spyridopoulos TN, Matsoukis IL, Kondi-Pafiti A, Zografos G \& Mantzoros CS 2011 Serum adiponectin levels and tissue expression of adiponectin receptors are associated with risk, stage, and grade of colorectal cancer. Metabolism 60 1530-1538. (doi:10.1016/j.metabol.2011. 03.020)

Goya M, Miyamoto S, Nagai K, Ohki Y, Nakamura K, Shitara K, Maeda H, Sangai T, Kodama K, Endoh Y et al. 2004 Growth inhibition of human prostate cancer cells in human adult bone implanted into nonobese diabetic/severe combined immunodeficient mice by a ligand-specific antibody to human insulin-like growth factors. Cancer Research 64 6252-6258. (doi:10.1158/0008-5472.CAN04-0919)

Grosfeld A, Andre J, Hauguel-De Mouzon S, Berra E, Pouyssegur J \& Guerre-Millo M 2002 Hypoxia-inducible factor 1 transactivates the human leptin gene promoter. Journal of Biological Chemistry 277 42953-42957. (doi:10.1074/jbc.M206775200)

Grossmann M, Thomas MC, Panagiotopoulos S, Sharpe K, Macisaac RJ, Clarke S, Zajac JD \& Jerums G 2008 Low testosterone levels are common and associated with insulin resistance in men with diabetes. Journal of Clinical Endocrinology and Metabolism 93 1834-1840. (doi:10.1210/jc.2007-2177)

Guigas B, Bertrand L, Taleux N, Foretz M, Wiernsperger N, Vertommen D, Andreelli F, Viollet B \& Hue L 2006 5-Aminoimidazole-4-carboxamide-1-beta-D-ribofuranoside and metformin inhibit hepatic glucose phosphorylation by an AMP-activated protein kinase-independent effect on glucokinase translocation. Diabetes 55 865-874. (doi:10.2337/diabetes.55.04.06.db05-1178)

Gunter MJ, Hoover DR, Yu H, Wassertheil-Smoller S, Manson JE, Li J, Harris TG, Rohan TE, Xue X, Ho GY et al. 2008 a A prospective evaluation of insulin and insulin-like growth factor-I as risk factors for endometrial cancer. Cancer Epidemiology, Biomarkers \& Prevention 17 921-929. (doi:10.1158/1055-9965.EPI-07-2686)
Gunter MJ, Hoover DR, Yu H, Wassertheil-Smoller S, Rohan TE, Manson JE, Howard BV, Wylie-Rosett J, Anderson GL, Ho GY et al. $2008 b$ Insulin, insulin-like growth factor-I, endogenous estradiol, and risk of colorectal cancer in postmenopausal women. Cancer Research 68 329-337. (doi:10.1158/0008-5472.CAN-07-2946)

Gunter MJ, Hoover DR, Yu H, Wassertheil-Smoller S, Rohan TE, Manson JE, Li J, Ho GY, Xue X, Anderson GL et al. 2009 Insulin, insulin-like growth factor-I, and risk of breast cancer in postmenopausal women. Journal of the National Cancer Institute 101 48-60.

Hakkak R, Holley AW, Macleod SL, Simpson PM, Fuchs GJ, Jo CH, Kieber-Emmons T \& Korourian S 2005 Obesity promotes 7,12-dimethylbenz(a)anthracene-induced mammary tumor development in female Zucker rats. Breast Cancer Research 7 R627-R633. (doi:10.1186/ bcr1263)

Haluska P, Carboni JM, Loegering DA, Lee FY, Wittman M, Saulnier MG, Frennesson DB, Kalli KR, Conover CA, Attar RM et al. 2006 In vitro and in vivo antitumor effects of the dual insulin-like growth factor-I/insulin receptor inhibitor, BMS-554417. Cancer Research 66 362-371. (doi:10.1158/0008-5472.CAN-05-1107)

Haluska P, Shaw HM, Batzel GN, Yin D, Molina JR, Molife LR, Yap TA, Roberts ML, Sharma A, Gualberto A et al. 2007 Phase I dose escalation study of the anti insulin-like growth factor-I receptor monoclonal antibody CP-751,871 in patients with refractory solid tumors. Clinical Cancer Research 13 5834-5840. (doi:10.1158/1078-0432.CCR-071118)

Heidegger I, Pircher A, Klocker H \& Massoner P 2011 Targeting the insulin-like growth factor network in cancer therapy. Cancer Biology \& Therapy 11 701-707. (doi:10. 4161/cbt.11.8.14689)

Hemkens LG, Grouven U, Bender R, Gunster C, Gutschmidt S, Selke GW \& Sawicki PT 2009 Risk of malignancies in patients with diabetes treated with human insulin or insulin analogues: a cohort study. Diabetologia 52 1732-1744. (doi:10.1007/s00125-009-1418-4)

Herling A, Konig M, Bulik S \& Holzhutter HG 2011 Enzymatic features of the glucose metabolism in tumor cells. FEBS Journal 278 2436-2459. (doi:10.1111/j.17424658.2011.08174.x)

Huxley R, Ansary-Moghaddam A, Berrington de Gonzalez A, Barzi F \& Woodward M 2005 Type-II diabetes and pancreatic cancer: a meta-analysis of 36 studies. British Journal of Cancer 92 2076-2083. (doi:10.1038/sj.bjc. 6602619)

Ish-Shalom D, Christoffersen CT, Vorwerk P, SacerdotiSierra N, Shymko RM, Naor D \& De Meyts P 1997 Mitogenic properties of insulin and insulin analogues mediated by the insulin receptor. Diabetologia 40 (Suppl 2) S25-S31. (doi:10.1007/s001250051393)

Jee SH, Ohrr H, Sull JW, Yun JE, Ji M \& Samet JM 2005 Fasting serum glucose level and cancer risk in Korean men and women. Journal of the American Medical Association 293 194-202. (doi:10.1001/jama.293.2.194) 
Jenab M, Riboli E, Cleveland RJ, Norat T, Rinaldi S, Nieters A, Biessy C, Tjonneland A, Olsen A, Overvad K et al. 2007 Serum C-peptide, IGFBP-1 and IGFBP-2 and risk of colon and rectal cancers in the European Prospective Investigation into Cancer and Nutrition. International Journal of Cancer 121 368-376. (doi:10.1002/ijc.22697)

Jiralerspong S, Palla SL, Giordano SH, Meric-Bernstam F, Liedtke C, Barnett CM, Hsu L, Hung MC, Hortobagyi GN \& Gonzalez-Angulo AM 2009 Metformin and pathologic complete responses to neoadjuvant chemotherapy in diabetic patients with breast cancer. Journal of Clinical Oncology 27 3297-3302. (doi:10.1200/JCO.2009.19. 6410)

Jonasson JM, Ljung R, Talback M, Haglund B, Gudbjornsdottir S \& Steineck G 2009 Insulin glargine use and short-term incidence of malignancies - a populationbased follow-up study in Sweden. Diabetologia 52 1745-1754. (doi:10.1007/s00125-009-1444-2)

Kaaks R \& Lukanova A 2001 Energy balance and cancer: the role of insulin and insulin-like growth factor-I.

Proceedings of the Nutrition Society 60 91-106. (doi:10. 1079/PNS200070)

Kaaks R, Rinaldi S, Key TJ, Berrino F, Peeters PH, Biessy C, Dossus L, Lukanova A, Bingham S, Khaw KT et al. 2005 Postmenopausal serum androgens, oestrogens and breast cancer risk: the European prospective investigation into cancer and nutrition. Endocrine-Related Cancer 12 1071-1082. (doi:10.1677/erc.1.01038)

Kang J, Chen MH, Zhang Y, Moran BJ, Dosoretz DE, Katin MJ, Braccioforte MH, Salenius SA \& D'Amico AV 2011 Type of diabetes mellitus and the odds of Gleason score 8 to 10 prostate cancer. International Journal of Radiation Oncology, Biology, Physics 82 e463-e467. (doi:10.1016/j.ijrobp.2011.07.003)

Kasper JS \& Giovannucci E 2006 A meta-analysis of diabetes mellitus and the risk of prostate cancer. Cancer Epidemiology, Biomarkers \& Prevention 15 2056-2062. (doi:10.1158/1055-9965.EPI-06-0410)

Kelesidis I, Kelesidis T \& Mantzoros CS 2006 Adiponectin and cancer: a systematic review. British Journal of Cancer 94 1221-1225. (doi:10.1038/sj.bjc. 6603051)

Key T, Appleby P, Barnes I \& Reeves G 2002 Endogenous sex hormones and breast cancer in postmenopausal women: reanalysis of nine prospective studies. Journal of the National Cancer Institute 94 606-616. (doi:10.1093/ jnci/94.8.606)

Khalid S, Hwang D, Babichev Y, Kolli R, Altamentova S, Koren S, Goodwin PJ, Ennis M, Pollak M, Sonenberg N et al. 2010 Evidence for a tumor promoting effect of highfat diet independent of insulin resistance in HER2/Neu mammary carcinogenesis. Breast Cancer Research and Treatment 122 647-659. (doi:10.1007/s10549-0090586-8)

Kim KY, Baek A, Hwang JE, Choi YA, Jeong J, Lee MS, Cho DH, Lim JS, Kim KI \& Yang Y 2009 Adiponectinactivated AMPK stimulates dephosphorylation of AKT through protein phosphatase $2 \mathrm{~A}$ activation. Cancer Research 69 4018-4026. (doi:10.1158/0008-5472.CAN08-2641)

Kisfalvi K, Eibl G, Sinnett-Smith J \& Rozengurt E 2009 Metformin disrupts crosstalk between $G$ protein-coupled receptor and insulin receptor signaling systems and inhibits pancreatic cancer growth. Cancer Research 69 6539-6545. (doi:10.1158/0008-5472.CAN-09-0418)

Kobayashi N, Barnard RJ, Said J, Hong-Gonzalez J, Corman DM, Ku M, Doan NB, Gui D, Elashoff D, Cohen P et al. 2008 Effect of low-fat diet on development of prostate cancer and Akt phosphorylation in the Hi-Myc transgenic mouse model. Cancer Research 68 3066-3073. (doi:10.1158/0008-5472.CAN-07-5616)

Konturek PC, Burnat G, Rau T, Hahn EG \& Konturek S 2008 Effect of adiponectin and ghrelin on apoptosis of Barrett adenocarcinoma cell line. Digestive Diseases and Sciences 53 597-605. (doi:10.1007/s10620-0079922-1)

Krone CA \& Ely JT 2005 Controlling hyperglycemia as an adjunct to cancer therapy. Integrated Cancer Therapy 4 25-31. (doi:10.1177/1534735404274167)

Kuriyama S, Tsubono Y, Hozawa A, Shimazu T, Suzuki Y, Koizumi Y, Ohmori K, Nishino Y \& Tsuji I 2005 Obesity and risk of cancer in Japan. International Journal of Cancer 113 148-157. (doi:10.1002/ijc.20529)

Lacy MQ, Alsina M, Fonseca R, Paccagnella ML, Melvin CL, Yin D, Sharma A, Enriquez Sarano M, Pollak M, Jagannath S et al. 2008 Phase I, pharmacokinetic and pharmacodynamic study of the anti-insulin-like growth factor type 1 receptor monoclonal antibody CP-751,871 in patients with multiple myeloma. Journal of Clinical Oncology 26 3196-3203. (doi:10.1200/JCO.2007.15.9319)

Landman GW, Kleefstra N, van Hateren KJ, Groenier KH, Gans RO \& Bilo HJ 2010 Metformin associated with lower cancer mortality in type 2 diabetes: ZODIAC- 16 . Diabetes Care 33 322-326. (doi:10.2337/dc09-1380)

Larsson SC, Orsini N \& Wolk A 2005 Diabetes mellitus and risk of colorectal cancer: a meta-analysis. Journal of the National Cancer Institute 97 1679-1687. (doi:10.1093/ jnci/dji375)

Larsson SC, Mantzoros CS \& Wolk A 2007 Diabetes mellitus and risk of breast cancer: a meta-analysis. International Journal of Cancer 121 856-862. (doi:10.1002/ijc.22717)

Lee AV, Jackson JG, Gooch JL, Hilsenbeck SG, Coronado-Heinsohn E, Osborne CK \& Yee D 1999 Enhancement of insulin-like growth factor signaling in human breast cancer: estrogen regulation of insulin receptor substrate-1 expression in vitro and in vivo. Molecular Endocrinology 13 787-796. (doi:10.1210/me. 13.5.787)

LeRoith D \& Roberts CT Jr 2003 The insulin-like growth factor system and cancer. Cancer Letters 195 127-137. (doi:10.1016/S0304-3835(03)00159-9)

Leung G, Benzie IF, Cheung A, Tsao SW \& Wong YC 2002 No effect of a high-fat diet on promotion of sex 
hormone-induced prostate and mammary carcinogenesis in the Noble rat model. British Journal of Nutrition $\mathbf{8 8}$ 399-409. (doi:10.1079/BJN2002673)

Levine AJ, Feng Z, Mak TW, You H \& Jin S 2006 Coordination and communication between the p53 and IGF-1-AKT-TOR signal transduction pathways. Genes and Development 20 267-275. (doi:10.1101/gad.1363206)

Liu M \& Liu F 2010 Transcriptional and post-translational regulation of adiponectin. Biochemical Journal $\mathbf{4 2 5}$ 41-52. (doi:10.1042/BJ20091045)

Ma J, Giovannucci E, Pollak M, Leavitt A, Tao Y, Gaziano JM \& Stampfer MJ 2004 A prospective study of plasma C-peptide and colorectal cancer risk in men. Journal of the National Cancer Institute 96 546-553. (doi:10.1093/jnci/djh082)

Ma J, Li H, Giovannucci E, Mucci L, Qiu W, Nguyen PL, Gaziano JM, Pollak M \& Stampfer MJ 2008 Prediagnostic body-mass index, plasma C-peptide concentration, and prostate cancer-specific mortality in men with prostate cancer: a long-term survival analysis. Lancet Oncology 9 1039-1047. (doi:10.1016/S1470-2045(08)70235-3)

Maffei M, Fei H, Lee GH, Dani C, Leroy P, Zhang Y, Proenca R, Negrel R, Ailhaud G \& Friedman JM 1995 Increased expression in adipocytes of ob RNA in mice with lesions of the hypothalamus and with mutations at the db locus. PNAS 92 6957-6960. (doi:10.1073/pnas.92. 15.6957)

Major JM, Laughlin GA, Kritz-Silverstein D, Wingard DL \& Barrett-Connor E 2010 Insulin-like growth factor-I and cancer mortality in older men. Journal of Clinical Endocrinology and Metabolism 95 1054-1059. (doi:10. 1210/jc.2009-1378)

Mantzoros C, Petridou E, Dessypris N, Chavelas C, Dalamaga M, Alexe DM, Papadiamantis Y,

Markopoulos C, Spanos E, Chrousos G et al. 2004 Adiponectin and breast cancer risk. Journal of Clinical Endocrinology and Metabolism 89 1102-1107. (doi:10. 1210/jc.2003-031804)

Mathieu MC, Clark GM, Allred DC, Goldfine ID \& Vigneri R 1997 Insulin receptor expression and clinical outcome in node-negative breast cancer. Proceedings of the Association of American Physicians 109 565-571.

Matsunaka T, Miyamoto S, Shitara K, Ochiai A \& Chiba T 2010 Ligand-specific antibodies to insulin-like growth factors suppress intestinal polyp formation in Apc $+/-$ mice. Molecular Cancer Therapeutics 9 419-428. (doi:10.1158/1535-7163.MCT-09-0524)

McTernan PG, Anwar A, Eggo MC, Barnett AH, Stewart PM \& Kumar S 2000 Gender differences in the regulation of $\mathrm{P} 450$ aromatase expression and activity in human adipose tissue. International Journal of Obesity and Related Metabolic Disorders 24 875-881. (doi:10.1038/sj.ijo. 0801254)

Michels KB, Solomon CG, Hu FB, Rosner BA, Hankinson SE, Colditz GA \& Manson JE 2003 Type 2 diabetes and subsequent incidence of breast cancer in the Nurses' Health Study. Diabetes Care 26 1752-1758. (doi:10.2337/diacare. 26.6.1752)

Mitin T, Chen MH, Zhang Y, Moran BJ, Dosoretz DE, Katin MJ, Braccioforte MH, Salenius SA \& D'Amico AV 2011 Diabetes mellitus, race and the odds of high grade prostate cancer in men treated with radiation therapy. Journal of Urology 186 2233-2238. (doi:10.1016/j.juro. 2011.07.072)

Moorehead RA, Hojilla CV, De Belle I, Wood GA, Fata JE, Adamson ED, Watson KL, Edwards DR \& Khokha R 2003 Insulin-like growth factor-II regulates PTEN expression in the mammary gland. Journal of Biological Chemistry 278 50422-50427. (doi:10.1074/jbc. M306894200)

Morcavallo A, Gaspari M, Pandini G, Palummo A, Cuda G, Larsen MR, Vigneri R \& Belfiore A 2011 Research resource: new and diverse substrates for the insulin receptor isoform A revealed by quantitative proteomics after stimulation with IGF-II or insulin. Molecular Endocrinology 25 1456-1468. (doi:10.1210/me.20100484)

Mosthaf L, Grako K, Dull TJ, Coussens L, Ullrich A \& McClain DA 1990 Functionally distinct insulin receptors generated by tissue-specific alternative splicing. EMBO Journal 9 2409-2413.

Novosyadlyy R, Lann DE, Vijayakumar A, Rowzee A, Lazzarino DA, Fierz Y, Carboni JM, Gottardis MM, Pennisi PA, Molinolo AA et al. 2010 Insulin-mediated acceleration of breast cancer development and progression in a nonobese model of type 2 diabetes. Cancer Research 70 741-751. (doi:10.1158/0008-5472.CAN-092141)

Nunez NP, Oh WJ, Rozenberg J, Perella C, Anver M, Barrett JC, Perkins SN, Berrigan D, Moitra J, Varticovski L et al. 2006 Accelerated tumor formation in a fatless mouse with type 2 diabetes and inflammation. Cancer Research 66 5469-5476. (doi:10.1158/0008-5472. CAN-05-4102)

Nunez NP, Perkins SN, Smith NC, Berrigan D, Berendes DM, Varticovski L, Barrett JC \& Hursting SD 2008 Obesity accelerates mouse mammary tumor growth in the absence of ovarian hormones. Nutrition and Cancer 60 534-541. (doi:10.1080/01635580 801966195)

Onuma M, Bub JD, Rummel TL \& Iwamoto Y 2003 Prostate cancer cell-adipocyte interaction: leptin mediates androgen-independent prostate cancer cell proliferation through c-Jun NH2-terminal kinase. Journal of Biological Chemistry 278 42660-42667. (doi:10.1074/jbc. M304984200)

Pan SY, Johnson KC, Ugnat AM, Wen SW \& Mao Y 2004 Association of obesity and cancer risk in Canada. American Journal of Epidemiology 159 259-268. (doi:10. 1093/aje/kwh041)

Pandini G, Vigneri R, Costantino A, Frasca F, Ippolito A, Fujita-Yamaguchi Y, Siddle K, Goldfine ID \& Belfiore A 
1999 Insulin and insulin-like growth factor-I (IGF-I) receptor overexpression in breast cancers leads to insulin/IGF-I hybrid receptor overexpression: evidence for a second mechanism of IGF-I signaling. Clinical Cancer Research 5 1935-1944.

Park HY, Kwon HM, Lim HJ, Hong BK, Lee JY, Park BE, Jang Y, Cho SY \& Kim HS 2001 Potential role of leptin in angiogenesis: leptin induces endothelial cell proliferation and expression of matrix metalloproteinases in vivo and in vitro. Experimental \& Molecular Medicine $\mathbf{3 3}$ 95-102.

Park IJ, Lee YK, Hwang JT, Kwon DY, Ha J \& Park OJ 2009 Green tea catechin controls apoptosis in colon cancer cells by attenuation of $\mathrm{H}_{2} \mathrm{O}_{2}$-stimulated COX-2 expression via the AMPK signaling pathway at low-dose $\mathrm{H}_{2} \mathrm{O}_{2}$. Annals of the New York Academy of Sciences 1171 538-544. (doi:10.1111/j.1749-6632.2009.04698.x)

Patterson RE, Flatt SW, Saquib N, Rock CL, Caan BJ, Parker BA, Laughlin GA, Erickson K, Thomson CA, Bardwell WA et al. 2010 Medical comorbidities predict mortality in women with a history of early stage breast cancer. Breast Cancer Research and Treatment 122 859-865. (doi:10.1007/s10549-010-0732-3)

Paz-Filho G, Lim EL, Wong ML \& Licinio J 2011 Associations between adipokines and obesity-related cancer. Frontiers in Bioscience 16 1634-1650. (doi:10. 2741/3810)

Peairs KS, Barone BB, Snyder CF, Yeh HC, Stein KB, Derr RL, Brancati FL \& Wolff AC 2011 Diabetes mellitus and breast cancer outcomes: a systematic review and meta-analysis. Journal of Clinical Oncology 29 40-46. (doi:10.1200/JCO.2009.27.3011)

Pelucchi C, Serraino D, Negri E, Montella M, Dellanoce C, Talamini R \& La Vecchia C 2011 The metabolic syndrome and risk of prostate cancer in Italy. Annals of Epidemiology 21 835-841. (doi:10.1016/j.annepidem. 2011.07.007)

Perks CM, Vernon EG, Rosendahl AH, Tonge D \& Holly JM 2007 IGF-II and IGFBP-2 differentially regulate PTEN in human breast cancer cells. Oncogene 26 5966-5972. (doi:10.1038/sj.onc.1210397)

Pollak MN, Polychronakos C, Yousefi S \& Richard M 1988 Characterization of insulin-like growth factor I (IGF-I) receptors of human breast cancer cells. Biochemical and Biophysical Research Communications 154 326-331. (doi:10.1016/0006-291X(88)90688-2)

Rapp K, Schroeder J, Klenk J, Ulmer H, Concin H, Diem G, Oberaigner W \& Weiland SK 2006 Fasting blood glucose and cancer risk in a cohort of more than 140,000 adults in Austria. Diabetologia 49 945-952. (doi:10.1007/s00125006-0207-6)

Rattan R, Giri S, Hartmann LC \& Shridhar V 2011 Metformin attenuates ovarian cancer cell growth in an AMP-kinase dispensable manner. Journal of Cellular and Molecular Medicine 15 166-178. (doi:10.1111/j.15824934.2009.00954.x)
Reeves GK, Pirie K, Beral V, Green J, Spencer E \& Bull D 2007 Cancer incidence and mortality in relation to body mass index in the Million Women Study: cohort study. BMJ 335 1134. (doi:10.1136/bmj.39367. 495995.AE)

Reiling JH \& Sabatini DM 2006 Stress and mTORture signaling. Oncogene 25 6373-6383. (doi:10.1038/sj.onc. 1209889)

Renehan AG 2011 Insulin analogues and cancer risk: the emergence of second-generation studies. Diabetologia $\mathbf{5 5}$ 7-9. (doi:10.1007/s00125-011-2352-9)

Renehan AG, Zwahlen M, Minder C, O’Dwyer ST, Shalet SM \& Egger M 2004 Insulin-like growth factor (IGF)-I, IGF binding protein-3, and cancer risk: systematic review and meta-regression analysis. Lancet 363 1346-1353. (doi:10.1016/S0140-6736(04)16044-3)

Rinaldi S, Cleveland R, Norat T, Biessy C, Rohrmann S, Linseisen J, Boeing H, Pischon T, Panico S, Agnoli C et al. 2010 Serum levels of IGF-I, IGFBP-3 and colorectal cancer risk: results from the EPIC cohort, plus a metaanalysis of prospective studies. International Journal of Cancer 126 1702-1715.

del Rincon JP, Iida K, Gaylinn BD, McCurdy CE, Leitner JW, Barbour LA, Kopchick JJ, Friedman JE, Draznin B \& Thorner MO 2007 Growth hormone regulation of p85alpha expression and phosphoinositide 3-kinase activity in adipose tissue: mechanism for growth hormone-mediated insulin resistance. Diabetes 56 1638-1646. (doi:10.2337/ db06-0299)

Rose DP, Hatala MA, Connolly JM \& Rayburn J 1993 Effect of diets containing different levels of linoleic acid on human breast cancer growth and lung metastasis in nude mice. Cancer Research 53 4686-4690.

Ruiter R, Visser LE, van Herk-Sukel MP, Coebergh JW, Haak HR, Geelhoed-Duijvestijn PH, Straus SM, Herings RM \& Stricker BH 2012 Risk of cancer in patients on insulin glargine and other insulin analogues in comparison with those on human insulin: results from a large population-based follow-up study. Diabetologia 55 51-62. (doi:10.1007/s00125011-2312-4)

Sachdev D, Zhang X, Matise I, Gaillard-Kelly M \& Yee D 2010 The type I insulin-like growth factor receptor regulates cancer metastasis independently of primary tumor growth by promoting invasion and survival. Oncogene 29 251-262. (doi:10.1038/onc.2009.316)

Samani AA, Yakar S, LeRoith D \& Brodt P 2007 The role of the IGF system in cancer growth and metastasis: overview and recent insights. Endocrine Reviews 28 20-47. (doi:10.1210/er.2006-0001)

Saxena NK \& Sharma D 2010 Metastasis suppression by adiponectin: LKB1 rises up to the challenge. Cell Adhesion \& Migration 4 358-362. (doi:10.4161/cam.4.3. 11541)

Schrauder MG, Fasching PA, Haberle L, Lux MP, Rauh C, Hein A, Bayer CM, Heusinger K, Hartmann A, Strehl JD 
et al. 2011 Diabetes and prognosis in a breast cancer cohort. Journal of Cancer Research and Clinical Oncology 137 975-983. (doi:10.1007/s00432-010-0960-2)

Sciacca L, Costantino A, Pandini G, Mineo R, Frasca F, Scalia P, Sbraccia P, Goldfine ID, Vigneri R \& Belfiore A 1999 Insulin receptor activation by IGF-II in breast cancers: evidence for a new autocrine/paracrine mechanism. Oncogene 18 2471-2479. (doi:10.1038/sj. onc.1202600)

Sciacca L, Mineo R, Pandini G, Murabito A, Vigneri R \& Belfiore A 2002 In IGF-I receptor-deficient leiomyosarcoma cells autocrine IGF-II induces cell invasion and protection from apoptosis via the insulin receptor isoform A. Oncogene 21 8240-8250. (doi:10.1038/sj.onc. 1206058)

Shaneyfelt T, Husein R, Bubley G \& Mantzoros CS 2000 Hormonal predictors of prostate cancer: a meta-analysis. Journal of Clinical Oncology 18 847-853.

Sierra-Honigmann MR, Nath AK, Murakami C, GarciaCardena G, Papapetropoulos A, Sessa WC, Madge LA, Schechner JS, Schwabb MB, Polverini PJ et al. 1998 Biological action of leptin as an angiogenic factor. Science 281 1683-1686. (doi:10.1126/science.281.5383. 1683)

Somasundar P, Frankenberry KA, Skinner H, Vedula G, McFadden DW, Riggs D, Jackson B, Vangilder R, Hileman SM \& Vona-Davis LC 2004 Prostate cancer cell proliferation is influenced by leptin. Journal of Surgical Research 118 71-82. (doi:10.1016/j.jss.2004.01.017)

Soos MA, Field CE \& Siddle K 1993 Purified hybrid insulin/insulin-like growth factor-I receptors bind insulinlike growth factor-I, but not insulin, with high affinity. Biochemical Journal 290 419-426.

Stocks T, Lukanova A, Rinaldi S, Biessy C, Dossus L, Lindahl B, Hallmans G, Kaaks R \& Stattin P 2007 Insulin resistance is inversely related to prostate cancer: a prospective study in Northern Sweden. International Journal of Cancer 120 2678-2686. (doi:10.1002/ijc. 22587)

Suissa S, Azoulay L, Dell'Aniello S, Evans M, Vora J \& Pollak M 2011 Long-term effects of insulin glargine on the risk of breast cancer. Diabetologia 54 2254-2262. (doi:10.1007/s00125-011-2190-9)

Szlosarek P, Charles KA \& Balkwill FR 2006 Tumour necrosis factor-alpha as a tumour promoter. European Journal of Cancer 42 745-750. (doi:10.1016/j.ejca.2006. 01.012)

Toniolo PG, Levitz M, Zeleniuch-Jacquotte A, Banerjee S, Koenig KL, Shore RE, Strax P \& Pasternack BS 1995 A prospective study of endogenous estrogens and breast cancer in postmenopausal women. Journal of the National Cancer Institute 87 190-197. (doi:10.1093/jnci/87.3.190)

Tran TT, Gupta N, Goh T, Naigamwalla D, Chia MC, Koohestani N, Mehrotra S, McKeown-Eyssen G, Giacca A \& Bruce WR 2003 Direct measure of insulin sensitivity with the hyperinsulinemic-euglycemic clamp and surrogate measures of insulin sensitivity with the oral glucose tolerance test: correlations with aberrant crypt foci promotion in rats. Cancer Epidemiology, Biomarkers \& Prevention 12 47-56.

Trayhurn P \& Wood IS 2004 Adipokines: inflammation and the pleiotropic role of white adipose tissue. British Journal of Nutrition 92 347-355. (doi:10.1079/ BJN20041213)

Turturro F, Friday E \& Welbourne T 2007 Hyperglycemia regulates thioredoxin-ROS activity through induction of thioredoxin-interacting protein (TXNIP) in metastatic breast cancer-derived cells MDA-MB-231. BMC Cancer 7 96. (doi:10.1186/1471-2407-7-96)

Tworoger SS, Rosner BA, Willett WC \& Hankinson SE 2011 The combined influence of multiple sex and growth hormones on risk of postmenopausal breast cancer: a nested case-control study. Breast Cancer Research 13 R99. (doi:10.1186/bcr3040)

Vander Heiden MG 2011 Targeting cancer metabolism: a therapeutic window opens. Nature Reviews. Drug Discovery 10 671-684. (doi:10.1038/nrd3504)

Vella V, Pandini G, Sciacca L, Mineo R, Vigneri R, Pezzino V \& Belfiore A 2002 A novel autocrine loop involving IGF-II and the insulin receptor isoform-A stimulates growth of thyroid cancer. Journal of Clinical Endocrinology and Metabolism 87 245-254. (doi:10.1210/jc.87.1.245)

Venkateswaran V, Haddad AQ, Fleshner NE, Fan R, Sugar LM, Nam R, Klotz LH \& Pollak M 2007 Association of diet-induced hyperinsulinemia with accelerated growth of prostate cancer ( $\mathrm{LNCaP}$ ) xenografts. Journal of the National Cancer Institute 99 1793-1800. (doi:10.1093/ jnci/djm231)

Verlato G, Zoppini G, Bonora E \& Muggeo M 2003 Mortality from site-specific malignancies in type 2 diabetic patients from Verona. Diabetes Care $\mathbf{2 6}$ 1047-1051. (doi:10.2337/diacare.26.4.1047)

Vigneri P, Frasca F, Sciacca L, Pandini G \& Vigneri R 2009 Diabetes and cancer. Endocrine-Related Cancer 16 1103-1123. (doi:10.1677/ERC-09-0087)

Wang Y, Lipari P, Wang X, Hailey J, Liang L, Ramos R, Liu M, Pachter JA \& Bishop WR 2010 A fully human insulin-like growth factor-I receptor antibody $\mathrm{SCH}$ 717454 (Robatumumab) has antitumor activity as a single agent and in combination with cytotoxics in pediatric tumor xenografts. Molecular Cancer Therapeutics 9 410-418. (doi:10.1158/1535-7163.MCT-09-0555)

Werny DM, Saraiya M \& Gregg EW 2006 Prostate-specific antigen values in diabetic and nondiabetic US men, 2001-2002. American Journal of Epidemiology 164 978-983. (doi:10.1093/aje/kwj311)

Wild S, Roglic G, Green A, Sicree R \& King H 2004 Global prevalence of diabetes: estimates for the year 2000 and projections for 2030. Diabetes Care 27 1047-1053. (doi:10.2337/diacare.27.5.1047)

World Health Organization 2011a Diabetes Fact Sheet. World Health Organization $2011 b$ Obesity and Overweight Fact Sheet. 
Wozniak SE, Gee LL, Wachtel MS \& Frezza EE 2009

Adipose tissue: the new endocrine organ? A review article Digestive Diseases and Sciences 54 1847-1856. (doi:10.1007/s10620-008-0585-3)

Wu C, Moreira DM, Gerber L, Rittmaster RS, Andriole GL \& Freedland SJ 2011 Diabetes and prostate cancer risk in the REDUCE trial. Prostate Cancer and Prostatic Disease 14 326-331. (doi:10.1038/pcan.2011.28)

Xue F \& Michels KB 2007 Diabetes, metabolic syndrome, and breast cancer: a review of the current evidence. American Journal of Clinical Nutrition 86 s823-s835.

Yakar S, Leroith D \& Brodt P 2005 The role of the growth hormone/insulin-like growth factor axis in tumor growth and progression: lessons from animal models. Cytokine \& Growth Factor Reviews 16 407-420. (doi:10.1016/j. cytogfr.2005.01.010)

Yancik R, Wesley MN, Ries LA, Havlik RJ, Edwards BK \& Yates JW 2001 Effect of age and comorbidity in postmenopausal breast cancer patients aged 55 years and older. Journal of the American Medical Association 285 885-892. (doi:10.1001/jama.285.7.885)

Zakikhani M, Dowling R, Fantus IG, Sonenberg N \& Pollak M 2006 Metformin is an AMP kinase-dependent growth inhibitor for breast cancer cells. Cancer Research 66 10269-10273. (doi:10.1158/0008-5472. CAN-06-1500)

Zeleniuch-Jacquotte A, Shore RE, Koenig KL, Akhmedkhanov A, Afanasyeva Y, Kato I, Kim MY, Rinaldi S, Kaaks R \& Toniolo P 2004 Postmenopausal levels of oestrogen, androgen, and SHBG and breast cancer: long-term results of a prospective study. British Journal of Cancer 90 153-159. (doi:10.1038/sj.bjc. 6601517)

Zhou J, Huang W, Tao R, Ibaragi S, Lan F, Ido Y, Wu X, Alekseyev YO, Lenburg ME, Hu GF et al. 2009 Inactivation of AMPK alters gene expression and promotes growth of prostate cancer cells. Oncogene $\mathbf{2 8}$ 1993-2002. (doi:10.1038/onc.2009.63)

Zib I \& Raskin P 2006 Novel insulin analogues and its mitogenic potential. Diabetes, Obesity \& Metabolism 8 611-620. (doi:10.1111/j.1463-1326.2005.00567.x)

Received in final form 17 January 2012 Accepted 20 January 2012 